\title{
ENTREVISTA COM DARCY RIBEIRO
}

\section{Luís Donisete Benzi Grupioni}

\section{Maria Denise Fajardo Grupioni}

Universidade de São Paulo - Brasil

\section{Apresentação}

No dia 17 de fevereiro de 1997, uma terça-feira, morreu, em Brasília, Darcy Ribeiro. A comoção nacional que se seguiu a sua morte trouxe a tona a figura singular deste personagem que marcou a história política recente do país. Intelectual engajado, escritor consagrado, orador cativante, Darcy Ribeiro era adorado por aqueles com quem convivia. Era um daqueles brasileiros que tinha orgulho de sua nacionalidade e que gostava do Brasil. Sempre pronto a enfrentar polêmicas, não perdia oportunidade de dizer o que pensava, doesse a quem doesse. Inquieto e perspicaz, ele tinha muita indignação para colocar para fora e muitas idéias e projetos para tornar o Brasil melhor e mais justo. Era uma pessoa especial e sabia disso. Fazia questão das reverências: quando em algum debate ou palestra, o apresentador insinuasse que o prof. Darcy, figura notória, dispensava apresentações, ele interrompia, dizia que não dispensava nada e que adorava ouvir elogios a sua pessoa. Afirmava que tinha certeza que os receberia após a morte, mas que apreciava muito desfrutá-los já em vida.

Em 1995, Darcy Ribeiro ocupou as páginas dos principais jornais e dos programas de entrevista das emissoras de televisão para contar a peripécia de ter fugido de um hospital e estar concluindo um livro que explicava e dava sentido ao Brasil. No Senado Federal, defendia um novo projeto para a Lei de Diretrizes e Bases da Educação Nacional, entrando em conflito tanto com a esquerda quanto com a direita. Nesse mesmo ano, recebia o título de Honoris Causa na Universidade de Brasília, da qual foi o idealizador, e tomava parte na inauguração do Memorial dos Povos Indígenas em Brasília, ocasião em que o Governo do Distrito Federal lançava o prêmio Darcy Ribeiro para estudantes das escolas de $1^{\circ}$ e $2^{\circ}$ graus. Ganhava, assim, de roldão, as páginas dos principais jornais e revistas do país. Badalado por todos os lados e, com certeza satisfeito com as expressões 
de admiração e reconhecimento, que pipocavam por todos os lados, ele nos recebeu em seu gabinete, no Anexo II do Senado Federal, onde o procuramos para que nos desse um depoimento sobre sua vida e sua obra de antropólogo.

Perguntou o tema da entrevista e a forma como pretendíamos realizála. De pronto, recusou a proposta de fazê-la ali mesmo, ligando um pequeno gravador. Mas gostou da idéia de fazer um depoimento sobre suas pesquisas e seus livros de antropologia e propôs que a entrevista fosse feita em vídeo. Combinamos, então, para o fim de semana seguinte, no Rio de Janeiro: se o tempo estivesse bom, ele nos receberia em seu sítio, em Maricá; se o tempo não estivesse lá essas coisas, seria em seu apartamento, na rua Bolívar, em Copacabana. Com o apoio financeiro do Programa de Pós-Graduação em Antropologia Social da USP, encontramos com Darcy Ribeiro em seu apartamento na manhã de sábado, do dia 29 de abril. Feitas as apresentações, ele fica aguardando, pacientemente, que montemos os equipamentos para a gravação. Tudo pronto, pede para testar os equipamentos preventivamente: diz ter falado horas a fio para gravadores desligados e entrevistadores desatenciosos. Não era o nosso caso. Com uma pauta na mão e várias outras perguntas na cabeça, damos a ele o sinal para começar. Ele se ajeita na poltrona, faz ar de sério, olha para a câmara como profissional acostumado a lidar com a imprensa e diz um monte de palavrões. Ri, de forma sapeca, como alguém que acaba de fazer uma travessura, e pede que voltemos a fita para ver se gravou. Tudo registrado, ele diz que agora é sério. Começa a falar e não pára mais. Então nos lembramos do primeiro parágrafo de seu livro Testemunhos: "Todo entrevistador de rádio, jornal ou televisão sabe que nem é preciso me fazer pergunta; hasta ligar o gravador e me deixar falar, que falo. Incansavelmente. Para mim, pelo menos”.

Por sorte, durante as quase três horas de gravação, ele pára, toma água, pede um café ou simplesmente descansa: é quando conseguimos pedir a ele que aborde alguns temas de nossa pauta, preparada previamente. Sem segui-la, ao pé da letra, vai, casualmente, tocando em assuntos que nos interessavam. Ele parece não ter tempo, nem paciência para perguntas: fala fluente e ininterruptamente, lembrando datas, lugares e personagens. Às vezes lança olhares e pergunta se está bom, se o assunto está interessante, para imediatamente seguir em frente, de forma veloz e cativante.

Ele mesmo decide quando a entrevista acaba. Insistimos em mais algumas perguntas, mas ele diz estar cansado. Pede cópia das fitas para a Fundação Darcy Ribeiro, que ele está organizando e que deverá herdar seus livros e os direitos autorais de sua obra. Promete, então, uma nova sessão. 
Desta vez, na sua casa de praia em Maricá.

Quatro meses depois, no feriado de 7 de setembro, um outro sábado, ele nos recebe em Maricá. Deitado numa rede, vestido todo de branco, nos oferece uma caipirinha e nos manda caminhar na areia da praia e sentir a brisa do mar. Diz que teremos o dia todo, que já mandou preparar um peixe para o almoço e que devemos aproveitar o dia. Montamos os equipamentos na biblioteca da casa, que foi projetada e construída por Niemayer. Darcy senta-se confortavelmente, pega uma bengala e faz pose para falar. Desta vez, permite que façamos mais perguntas. Lá se vão mais umas três horas de conversa e gravação até que ele declara: “Chegou irmãozinho. Acabou.” Aí ele nos chama para mostrar as fotos de sua pesquisa entre os Urubu-Kaapor que estavam sendo selecionadas para o seu novo livro, Diários índios, e depois para o almoço, onde nos conta detalhes de sua fuga da UTI e de seu refúgio naquela casa. Final da tarde nos despedimos, agradecendo a oportunidade de ouvi-lo e com a certeza de que quem teve a chance de conhecê-lo, não o esquecerá.

Ainda estávamos trabalhando na transcrição deste depoimento, quando Darcy morreu. Sentimos sua morte, como a de alguém que perde uma pessoa muita próxima e querida, tamanha foi a intimidade com que ele nos tratou nestes dois encontros, em que empreendeu uma viagem no tempo para falar sobre sua carreira de antropólogo, construindo nexos entre sua obra e sua trajetória.

Uma parte deste depoimento foi publicada na Revista Cadernos de Campo (USP, Vol. 4), outra está disponível na homepage da ABA, no Boletim n. 27. Aqui o leitor tem o depoimento completo, com estes dois trechos e um outro que permanecia inédito. Agradecemos a revista Horizontes Antropológicos a possibilidade de publicá-lo na íntegra, propiciando aos leitores a oportunidade de também empreenderem uma viagem sobre momentos da história da antropologia brasileira através da vida e da obra de um de seus atores e autores ilustres, assim definido por Carlos Drumond de Andrade: “[...] Darcy é o cara mais Sete Quedas que eu conheci”.

\section{Entrevista}

\section{Como o senhor começou a se interessar pela antropologia?}

Darcy Ribeiro: Em 1942, eu conheci um exemplar de A origem da família, da propriedade privada e do Estado, do Engels. Foi uma coisa incrível, porque eu era estudante de medicina, e tomava bomba todo ano, tomei três vezes bomba, porque lia livros como esse do Engels, porque assistia cursos 
de filosofia, porque escrevia romances de trezentas páginas. Eu era estudante de medicina para agradar minha mãe. A Faculdade de Medicina não me interessava, o que me interessava estava fora da Faculdade. Naquela época do Estado Novo, Chico Campos, o chamado "Chico Ciência”, importava livros da Argentina e dos alemães que interessavam a ele. Ele importou vários livros marxistas, entre eles, A origem da família. O seu livreiro, Paulo Tederman, sempre reservava um exemplar para mim. Foi assim que eu li um livro sobre teoria da cultura, aos vinte anos. Eu não digo que tenha produzido qualquer efeito não. Mas será pura coincidência que esse primeiro livro teórico que eu li é o livro que fui escrever em 65/ 66 [O processo civilizatório], que eu publico em 68 no Smithsonian, que é a mais importante instituição científica no campo da antropologia? E claro que essas coisas não são pura coincidência, havia um olhar voltado para certas questões que permaneceria por muitos anos.

No período que eu estava em Minas Gerais, fazendo de conta que estudava medicina, mas lendo outros textos, eu não sei bem por que, mas consegui um nível de convivência e de participação em grupos de conversa de professores de filosofia e dos intelectuais mais importantes dali. Em essência, eu era um jovem inocente, falante e curioso. Eles achavam engraçado que eu perguntasse qualquer coisa. Então eu me lembro de duas inocências minhas que são tipológicas biograficamente. Uma delas é que eu quando cheguei lá em Belo Horizonte, aos 17 anos, eu cheguei falando contra o poema de Carlos Drummond "A pedra no meio do caminho". Meu discurso era que isso não era poesia e que o bom era Olavo Bilac. Um certo dia, eu me encontrei gostando daquilo. E foi incrível, porque eu que falava tanto mal disso e mudara de opinião. Então foi uma virada. E outra virada parecida, foi quando encontrei um livro de divulgação sobre história da filosofia. Eu devorei o livro, encantado por Sócrates e Platão, e eu dizia: "Porra, em Montes Claros não tem ninguém como esse Sócrates, nem em Belo Horizonte.” Então eu comecei a procurar homens sábios.

Naquele tempo, anos quarenta, eu era um jovem meio atípico. Havia uma guerra terrível lá fora, e aqui dentro uma guerra intelectual entre comunistas e integralistas. E eles faziam campanha para aliciar gente. Eu fui muito cotado, tanto pelos comunistas, quanto pelos integralistas. Não sei por que não fui integralista, eu gostava do discurso integralista, que era nacionalista, eu gostava dos livros que eles davam para a gente. Mas optei pelos comunistas, eu li uma biografia do Jorge Amado e, por alguma razão me identifiquei com os comunistas. O que foi muito bom. Os comunistas me deram o acesso a uma quantidade de livros que tinham um ponto de vista único sobre as coisas. O grande 
perigo para um intelectual, sobretudo mineiro, é a "erudição vadia”. Os meus colegas, quando eu voltei de São Paulo, dez anos depois, achavam que eu tinha "torrado" muito, tinha lido muito. Mas eu dizia que tinha lido muito menos que eles, porque o grande defeito da erudição vadia do mineiro, que é típica, é que ele leu tanto Sócrates, quanto Kant, quanto Marx, quanto todos. E quem leu todos não leu ninguém. Quem lê simplesmente por curiosidade intelectual, pode ser que chegue a ter uma certa ilustração sobre o pensamento, mas nunca chega a ter um pensamento. Então o fato de eu me identificar com os comunistas concatenou minhas leituras num certo rumo e é melhor um rumo denso que a dispersão. Eu fugi da dispersão mineira assim. A outra razão mais importante é que, de certa forma, o Partido Comunista fazia de cada membro um herdeiro responsável pelo destino humano. Então é uma atitude que faz com que você seja capaz de comover-se com o que acontece de ruim na guerra, ou de bom em alguma outra coisa, em qualquer lugar da Terra. Você é responsável pela humanidade. Essa atitude é o que mais falta hoje: os jovens serem ganhos para uma postura aberta para o mundo e generosa. Apesar do sectarismo envolvido, essa abertura realmente é uma coisa muito importante. Em vez de um jovem estar voltado para ganhar dinheiro ou para ter emprego, ele pode estar voltado para criar uma vida digna que é uma vida solidária.

Num certo momento, eu deixo Minas, convidado a ir para São Paulo, pelo Donald Pierson, da Escola de Sociologia e Política, que me daria uma bolsa de estudos. Foi um conflito com a minha família, eu estava fazendo 21 anos e ia entrar em posse de um dinheiro de herança. Eles acharam que era pura boêmia. Mas o fato é que eu tinha esgotado o que Belo Horizonte podia me dar, tendo em vista o rumo em que eu estava. Então eu inventei para o meu tio, que era meu tutor, uma teoria de que medicina é muito ruim porque trata com doente e doente fede muito, e que eu estava enjoado daquele negócio, que eu queria estudar o homem são, e que antropologia estuda o homem são. Uma conversa fiada!

Fui, então, para São Paulo, para a Escola de Sociologia e Política, onde recomecei o curso de Ciências Sociais, depois de ter cursado uma parte dele em Minas. Foi muito bom para mim. Na época eu era comunista e cheguei a ser orientador da célula dos motorneiros da Light. Esse convívio com operários, com motorneiros, que achavam engraçado aquele rapaz falante, era um convívio bom que me deu uma dimensão de São Paulo. Outra dimensão de São Paulo me foi dada pelos colegas da Faculdade de Direito, de Medicina e várias outras, todos brilhantes, ligados à UNE. Eles viviam procurando as moças ricas, e me apresentaram várias. Eu custei muito a entender que era uma 
coisa legítima um rapaz inteligente procurar um moça rica para casar, porque é um bom começo de vida. E uma moça rica não é besta, procura um rapaz inteligente também, para ajudar a tomar conta dos bens dela. Mas eu fiquei com um grande sectarismo em relação àquilo.

Eu vivia em São Paulo como estudante da Escola de Sociologia, com uma bolsa e com a renda que vinha da família. Então eu tinha uma vida mais ou menos frouxa, e fui profundamente influenciado pela Escola de Sociologia e Política, que não só me fez ler e conhecer a sociologia norte-americana, as correntes novas das Ciências Sociais, como fugir daquilo que eu chamava de erudição vadia, a enfermidade principal do espírito do brasileiro em geral e do mineiro, em particular, que é essa atitude de tomar a cultura como alguma coisa fluida. Durante o curso fui me identificando mais com uns professores do que com outros. Sérgio Buarque de Hollanda, por exemplo, para mim, foi um acontecimento: ele vinha da Alemanha e trazia uma visão de mundo diferente. O primeiro uísque que eu tomei na vida foi o Sérgio que me deu, no clubinho dos arquitetos. Já a relação que eu tinha com o Pierson e com outros professores era muito formal.

Depois me aproximei do Herbert Baldus, um antropólogo alemão da Escola de Thurnwald, que tinha a atitude básica do europeu. Os antropólogos europeus nunca foram antievolucionistas. Este era um pendor ou uma perversão norte-americana que se refletia no preconceito com a obra de Morgan, aquele antropólogo que escreveu o livro mais importante de história da evolução, no qual se baseou Engels para escrever $A$ origem da família, e que era um dos livros mais lidos na Europa. Isso criou nos Estados Unidos uma atitude sectária e puritana, contrária a quem contestasse a origem bíblica. Então, sem que a antropologia virasse a antropologia bíblica de Adão e Eva, ela deixou de tratar dos temas teóricos, e criou-se uma excelente antropologia burra, de vista curta, que era capaz de fazer monografias admiráveis, estudar temas específicos como parentesco ou mitologia, mas que, com isso, abria mão de sua vocação. A vocação da antropologia é elaborar uma teoria sobre o humano e sobre as variantes do humano e melhorar o discurso dos homens sobre os homens. É para isso que a ciência existe, e eu me interessava evidentemente por isso, mas o que entrava na escola como ensino formal não era isso. Exceto com Baldus, que era um homem atípico, Herbert Baldus era um poeta alemão antinazista: o único alemão antinazista que eu conhecia. Ele era casado com uma judia que estava sendo perseguida. Em função disto, deixou a Alemanha e foi morar em São Paulo.

Lá estavam, também naquela época, Radcliffe-Brown, que era a figura principal da antropologia inglesa, Emílio Willems, que era um grande 
sociólogo alemão; e tinha estado Lévi-Strauss, ou seja, havia um núcleo, na Escola de Sociologia e Política que fazia dela talvez o melhor núcleo do mundo em Ciências Sociais, porque tinha gente da melhor qualidade, e gente capaz de questionar. A antropologia estava muito mal na França, e a sociologia também, porque muito influenciadas pela filosofia alemã. Nos Estados Unidos, estavam influenciadas pelo Puritanismo. Havia, então, ali em São Paulo, um ambiente curioso. Não houve influência em mim dessas pessoas que eu citei, mas o ambiente que se criou, era um ambiente tão estranho, que era capaz de fazer uma coisa milagrosa, ou seja, catapultar um jovem ignorante que vinha de Minas para a tarefa de estudar o destino humano. Quer dizer, como é que eu, um jovenzinho de Montes Claros, ignorante, filho de criador de boi, que normalmente deveria ser vaqueiro, como é que eu vou estudar o humano e tentar fazer teoria sobre o humano? Como é que eu vou estudar os índios como testemunhas da formação humana? Realmente, eu devo isto àquele ambiente de São Paulo, que permitia ideais científicos muito altos. E, especificamente, aos seminários do Baldus, que durante anos eu freqüentei. Desses seminários saiu Egon Shaden, que foi professor durante anos e o melhor antropólogo da USP; o único que fez uma obra teórica relevante. Saiu Florestan Fernandes, que também fez estes seminários e saí eu. O Florestan estava, naquela época, muito empenhado em provar que se podia fazer estudos funcionalistas, com base em documentos. Fez a tese dele sobre isso. Ele queria ser o mestre dos documentos, dos textos escritos, e escreveu um livro admirável sobre a organização social Tupinambá. Então o Florestan se voltou para a reconstituição do que eram os Tupinambá e fez uma obra admirável. Eu, ao contrário, me voltei para ler na realidade, para estudar as populações indígenas.

Na verdade, eu não queria só índio. Eu tinha sido formado com um certo interesse pela observação direta; podia também ser sociólogo. Um dos empregos pelos quais eu podia optar era no Serviço do Patrimônio Histórico e Artístico Nacional, que tinha uma das melhores equipes do Brasil. Havia passado por ali Mário de Andrade e, na ocasião, ali estavam Rodrigo de Mello Franco, Lúcio Costa e Oscar Niemayer. Havia um emprego ali para mim que era para estudar os fundamentos da cultura material do século XVI, a cultura que o português trouxe: a tecnologia de fazer chapéu, sapato, tijolo, telha, açúcar, carro de boi; enfim, a tecnologia com que o Brasil foi construído. O Afonso de Mello e Franco tinha escrito um livro sobre isso com base nos documentos. E cumpria fazer isso por observação direta, porque essas coisas continuavam sendo feitas da mesma forma. 


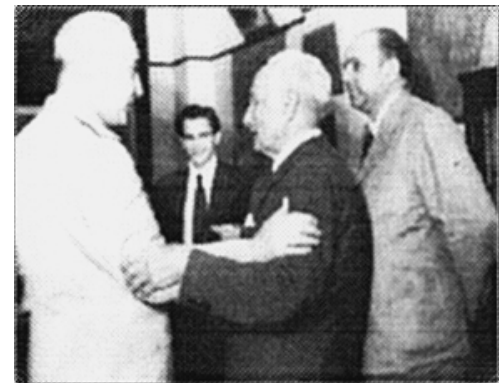

Darcy Ribeiro e Rondon (foto: arquivo Museu do índio).

O estudo da tecnologia rústica era um tema que me interessava já naquela época, e eu podia ir para lá. Mas o Baldus me deu uma carta de referência para o Rondon, e de repente eu fui levar a carta para o Rondon sem muita esperança; e ele acabou me oferecendo um emprego no Conselho de Proteção aos índios e no Serviço de Proteção aos índios, que funcionavam juntos. Não havia nome para aquele emprego, não havia, na escala de funcionários, antropólogos, nem etnólogos; havia naturalistas, e o meu primeiro contrato foi como naturalista. Eu fiquei uns meses aqui, no Rio, me preparando para a primeira pesquisa de campo.

Já antes eu tinha escolhido a minha pesquisa de campo, ou seja, ainda que tenha sido uma surpresa que eu conseguisse um emprego, não era surpresa para mim a possibilidade de me dedicar ao estudo da população indígena. Nisto a influência fundamental é do Baldus e também do Sérgio Buarque. O Sérgio era meu professor de História e eu tratava muito com ele de uma coisa que ninguém em São Paulo sabia, que era a história da população do Chaco e do Pantanal. E eu me encantei com a história dos Guaicuru. Assim como o Florestan queria fazer a reconstituição dos Tupinambá, eu queria estudar os Guaicuru, os índios cavaleiros, dos quais haviam representantes ainda. Eu estava me preparando para isso.

Naquele tempo, aos 24 ou 25 anos, eu continuava comunista ativo, queria muito ser comunista profissional e fiz contatos para isso. Foi então que o Joaquim da Câmara Ferreira, diretor do Jornal Hoje, prestes a passar um ano em Moscou, propôs que eu ficasse dirigindo o jornal do Partido. Diante disso, o Partido Comunista teve que tomar uma decisão, e, tendo mais juízo do que eu, avaliou que era loucura me entregar o jornal, como também era loucura me integrar como um quadro profissional. Então, disseram-me que tinham vários nomes sérios como Oscar Niemayer e como Portinari; que precisavam criar 
sábios para o futuro e que eu estava liberado. Então eu sou um caso estranho de liberação, eu não sou renegado, nem fugido, nem nada, fui licenciado pelo Partido Comunista para ser cientista. Para mim, foi uma decepção aquilo. Mas, no fundo, essas coisas foram decepcionantes, por um lado, e estimulantes, por outro. Era uma vida em que eu tomava opções aos vinte e poucos anos, e que me enchia, também, o coração. Depois disso passei uma temporada lendo muito em São Paulo, na Biblioteca Municipal, orientado pelo Sérgio. Aqui para o Rio, eu já vim contratado pelo Rondon. Trabalhei muito na Biblioteca Nacional, onde descobri documentos originais sobre os Guaicuru e pesquisei muito sobre eles.

\section{E como foi a sua primeira pesquisa de campo?}

Eu parti para o campo muito preparado, lendo tudo que me era acessível sobre o passado dos índios que iria pesquisar. Mas eu não sou besta, tinha medo de chegar lá e encarar o "meu povo", a "minha tribo", sem nunca ter visto um índio antes, e vendo o meu pela primeira vez. Então eu disse: "Agora não vou não!” Resolvi, primeiro, visitar todos os índios da região para ter uma base. Visitei todas as aldeias Terena e fiquei muito impressionado de ver os Terena muito aculturados. Havia desde Terena que só falava na própria língua, estes eram poucos, até Terena integrado na vida urbana de Campo Grande. Ver esse gradiente de um povo que se acerca da civilização, chega, e fica na porta, foi uma coisa que me impressionou. Depois fui ver os Guarani, porque eu já tinha lido muito sobre eles. E eles me impressionaram também, uma gente maltrapilha, feia, fétida pela quantidade de fumaça das fogueiras: estavam quase como que defumados, pois viviam com foguinhos debaixo das redes. Uma situação muito miserável. Mas eu custei a lavar meus olhos para vê-los. Então, de repente, também graças ao Nimuendajú, eu fui vendo, atrás daquela miséria, uma espiritualidade profunda. Uma gente voltada para coisas espirituais, para coisas intelectuais, uma gente que era capaz de ficar horas conversando sobre temas míticos. E tudo aquilo me parecia estranho: o Terena era um trabalhador braçal, era um enxadeiro, o interesse da cultura dele era elementar, ele exercia sua cultura como uma festa. Ele continuava Terena porque não havia lugar para ele na sociedade nacional, senão como índio. Mas os outros não, aqueles índios maltrapilhos lá, eram o povo Guarani, de milênios, guardando a mitologia, e com coisas absolutamente extraordinárias. Eles haviam transformado o mito da criação no mito da perdição, como o Nimuendajú mostrou. Quando o filho de Maíra, Deus Criador, fez grandes transformações no mundo, o pai se irritou muito e começou uma guerra do pai com o filho. Nesta guerra, o pai mandou 
o grande tigre azul, maior que o céu, matar o filho. Trata-se de uma guerra do grande tigre azul contra o filho. O filho mata o grande tigre azul, e com a pele dele faz o fundo do céu, com os olhos, faz o sol e a lua. Esta é uma concepção da origem do mundo. E os Guarani, de então, contavam esta história em termos de que a Terra está cansada, a Terra chora e diz: "Termina com isso pai, estou cansada de comer cadáver”, ou seja, a Terra volta-se para o grande tigre azul, trata-o de pai e pede para ele por um fim. Essa espiritualidade guarani teve um impacto muito grande em mim, como um outro modo de ser índio.

Havia um outro grupo indígena lá, que era o dos Ofaié-Xavante. Era um grupo de dois mil índios, ao princípio do século. Quando cheguei lá, tinha menos de dez, dos quais, cinco falavam a língua. Eu fui passar um mês com eles. Colhi a mitologia deles e vi o que é o fim de uma tribo, é uma coisa incrível. Naqueles dez índios, homens, mulheres e crianças, vivia um povo, com concepções sobre si mesmo, com uma mitologia, com costumes que não podia desempenhar. À margem de uma fazenda enorme e da mata mais rica do Brasil, mata de peroba, que a família Moura Andrade tinha apropriado, eles eram uns miseraveizinhos de uns indiozinhos. Mesmo o pedacinho de terra deles, os Moura Andrade queriam tirar. Com isso eu fiquei comovido sobre a necessidade de ampará-los contra os Moura Andrade. Eles tinham feito todo Oeste de São Paulo, inclusive fundaram uma cidade que se chama Andradina. Já tinham passado para o lado do Mato Grosso, onde estavam fazendo a mesma coisa, tinham fazendas do tamanho da Holanda. Esses indiozinhos perdidos no meio de uma fazenda, em que há uma vontade superior, que é a do dono da lei. Não sabendo de nada sobre isso, ali, tentando caçar, pescar, pedindo perdão por existir, ditaram uma mitologia, para mim muito expressiva. São justamente os mitos Ofaié, os principais mitos meus que o Lévi-Strauss interpretou.

Eu construí, desse modo, uma base de informações sobre a indianidade, para chegar, sem inocência, na minha tribo. Se eu não tivesse visto índio nenhum, eu teria tomado os meus índios, como "os índios”. Eu cheguei sabendo que eram "uns índios", era um modo de ser possível. A atitude deles, comigo, era uma atitude de orgulho. Ainda que muito pobres, despojados dos cavalos e do gado que eles tinham aos milhares, intoxicados com o aguardente, conseguiam sobreviver e guardar um orgulho de povo senhorial, achando-se superior a qualquer outro povo. Mas, eu não teria nem sequer percebido isso se não tivesse o cuidado de ver os outros grupos antes.

Estava eu, afinal, diante da minha tribo, os Kadiwéu, povo que eu tinha me preparado para estudar. Havia evidentes diferenças entre eles e os outros. 
Eles contrastavam com os outros índios pela independência mental e pela autonomia. Eles tinham um território muito grande, eram maiores e mais fortes, ainda que houvesse pouca comida e muita fome, porque os rapazes não faziam roça. A gente vigorosa de lá, mesmo sem nenhuma possibilidade de fazer guerra, continuava preparada para fazer guerra. Quem fazia roça eram os velhos e as mulheres. Então a quantidade de comida que havia era pequena.

Mas, no princípio, eu cometi um erro: comecei a conversar muito com os Terena que viviam por ali, porque eram mais falantes, mais humildes, dominavam mais o português. O problema era que os Kadiwéu tinham desprezo pelos Terena, os viam como escravos. Então, eu percebi que não podia continuar com aquele tipo de convívio e passei a procurar mais os Kadiwéu. Comecei o meu método que usei ao longo da vida, que é o de visitar casa por casa, fazer o esquema de parentesco, depois tentar conversar com eles sobre os laços que têm com os outros membros da mesma aldeia. Isso é uma coisa que desenvolvi em toda minha carreira de etnólogo e é muito bom porque, ao falar de parentesco, você não só aprende como fala de coisas que eles sabem e estão interessados: que fulano é irmão de beltrano por tal razão, ou é tio ou é avô, e aí você vê como toda aldeia está articulada. E isso me deu uma intimidade maior com eles.

Naquela ocasião ocorreu um acontecimento básico, fundamental para o meu relacionamento com o grupo, cuja causa foi puramente incidental: eu estava na varanda do posto indígena, na casa do administrador daquela reserva, deitado numa rede, olhando um livro do Guido Boggiani, um etnólogo italiano que tinha estado lá, no fim do século passado. Os índios vieram olhar o livro, que inclusive é muito ilustrado, e reconheceram imediatamente os desenhos deles, e começaram a perguntar: “De quem é esse papel?”, “Quem te deu esse papel?” Mas eu não podia explicar que tinha comprado numa livraria, fui “enrolando" e passando o livro. Num certo momento, eles reconheceram o retrato de uma mulher. Uma velha que estava ali, Anõa, que era a melhor desenhista e acabou fazendo mais de mil desenhos para mim, ficou muito emocionada e disse: “É Ligui, é Ligui” e chamava as outras para ver o retrato da mulher que ela tinha conhecido anos antes. Então, isto me ligava mais a eles e eles me perguntavam mais insistentemente porque eu tinha o retrato da Ligui e que papéis eram aqueles. Comecei a falar, então, de um homem que esteve lá, que desenhava muito, há muitos anos atrás e que tinha gostado muito deles. Aí eles identificaram: “Mas é Bet’rra, é Bet’rra”, que era o nome do Boggiani. Logo depois, me disseram que ele vivia lá e foi casado lá. Eu perguntei se ele teve filhos. Responderam que não, que ele fora casado com um homem, um rapagão 
bonito e viril. Eu contei a eles que o Boggiani, ao sair das aldeias deles, foi assassinado pelos Xamacoco, os inimigos deles. Com isso, o Boggiani virou um herói, porque era um homem deles e eles tinham que ter feito grandes cerimonias a ele porque tinha sido morto em guerra e nunca fizeram. Então aquela velha, Anoã, começou a entoar um canto para Ligui e para Boggiani, com os braços colados ao corpo e os antebraços livres, rodando sobre si mesma. Esta é forma da poesia que eles têm. Naquele momento, ela canta em versos que Bet'rra havia morrido e fala de Ligui e do marido de Bet'rra. A partir daquele momento, eu passei a ser chamado de Bet'rra-yegi, porque eles imaginavam o Bet'rra como sendo um homem muito alto, um italiano grande com um vozeirão. E eu era magrinho, pequinininho, o Bet'rrazinho. Então os meus nomes eram: doutor-yegi, o doutorzinho ou Bet'rra-yegi. Isso me deu um tipo de empatia com eles, que é muito raro um antropólogo ter. Eu era quase que como um membro da tribo, por causa do Bet'rra. Mas na verdade eu estava fora, era muito ignorante e que voltava, com todo o direito de perguntar qualquer coisa.

Eu fiz uma boa etnografia Kadiwéu, só não fiz melhor etnografia, porque eu era muito bisonho. Em todo caso, eu passei um longo período com eles, mais de oito meses, e no ano seguinte, fui novamente e passei mais oito meses. Foi uma expedição linda pelo Pantanal. O Pantanal de 50 anos atrás era muito mais maravilhoso do que hoje. Passei muito tempo acompanhando o rio Paraguai que derrama suas águas e depois volta ao leito, e toda a caça faz esse movimento. Esta foi uma pesquisa longa em que eu focalizei vários aspectos, especialmente o desenho, a mitologia, a religião e a arte desses índios. Foi um caso em que a pesquisa representou para mim, não só um modo de me acercar de um povo sobre o qual eu sabia do passado, muito mais do que eles próprios, mas de ver a forma presente, que era resultante daquele passado e que era impensável para qualquer pessoa que não fosse vê-los. E esses meses que eu passei com os índios, foram muito gratificantes. Quando eu voltava, meus amigos diziam que isso era um suicídio, que eu podia ter o emprego que quisesse e ficava metido no mato. Eles não sabiam que os melhores dias da minha vida eram os que eu passava com os índios.

Eu nunca tive o pendor para caçar, nunca cacei, nunca pesquei: para os índios eu era um bicho inútil e estranho que tinha que ser alimentado na boca, praticamente, porque eu não prestava para nada, ainda que tivesse arma muito boa. E eles faziam muitas sacanagens comigo. Numa delas, eles puseram um veado morto preso a um pau e me levaram lá, me fizeram dar uns quatro tiros, até eu verificar que ele estava morto e que eu só era capaz de matar 
um veado morto. Eles riam muito de mim por causa dessas coisas. Tinham comigo uma relação de intimidade que raramente antropólogo tem porque age como um funcionário, um senhor que está ali, eu era um dali. Lembro que às vezes eles perdiam a paciência comigo, terrivelmente. Tinha um índio, chamado Cardoso, que um dia não me bateu porque não podia, mas ficou irritadíssimo. O que aconteceu foi que a noite estava muito bonita, a via-láctea muito visível, o cruzeiro do sul também, estava lindo o céu, e eu comecei a tentar ver as constelações que ele identificava. Ele dizia: "Olha o bico da ema, o bico da ema, o bico da ema”, e eu não via, porque para mim não tinha bico da ema nenhum, para mim aquilo era uma estrela do cruzeiro do sul; mas para ele aquilo era tão evidente que ele não podia entender que eu não visse e dizia: “Mas você está cego, você não vê?”, e ficava irritadíssimo que eu não conseguisse ver o que, para ele, era evidente. Em outra ocasião eu saí com os índios e uma onça nos atacou, o cavalo da frente arrebentou os arreios e um índio caiu. Eu saí atrás da onça, mas eles saíram atrás de mim, porque, para eles o perigo era que a onça me comesse. E há milhares de episódios assim.

Na segunda expedição eu levei a minha mulher, Berta, que tinha vindo dos Estados Unidos. Ela estava mais ou menos preparada para ser etnóloga e aquela foi a primeira experiência dela. Ela sofreu muito, porque dentre as mulheres, uma ou outra falava algumas palavras em português comigo, mas com ela, não falavam nenhuma. Aquelas mulheres ficavam o tempo todo falando de mim e rindo para enciumá-la, isso deixava a Berta danada da vida com as índias, morrendo de ciúmes, porque ficava imaginando que alguma índia tivesse tido um caso comigo. Foi nessa época que tiramos aquelas fotografias com os rostos desenhados e que eu fiz uma grande coleção de desenhos Kadiwéu.

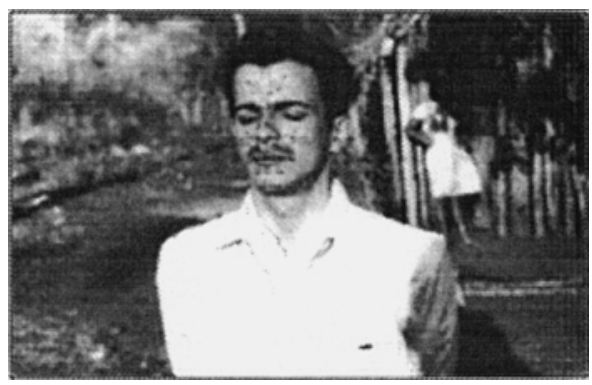

Darcy Ribeiro entre os Kadiwéu (foto: arquivo Museu do Índio). 


\section{Quais foram os resultados dessa pesquisa entre os Kadiwéu?}

A primeira coisa que publiquei como etnólogo é o que todo antropólogo sério deve publicar: uma terminologia de parentesco. Na verdade, eu era obrigado a fazer isso porque a antropologia fundamental era parentesco, tinha que saber, tinha que estudar parentesco, era uma espécie de prova. O interessante é que, uns trinta anos mais tarde, saiu um livro sobre parentesco nos Estados Unidos que trazia aquele meu artigo como um dos melhores. Selecionaram vinte artigos sobre parentesco e um deles era o meu. Eu acho que o meu era o melhor porque, ao invés de ficar naquela velha marca dos estudos de parentesco, eu mostrava a aplicação dos termos de parentesco ao escravo. Os Kadiwéu eram um povo que fazia escravos, apanhava crianças de dois anos em outras tribos e criava. Então havia todo um esquema em que o menino que chegava era chamado de "meu neto", depois o filho dele podia passar a "meu filho", o neto podia ser “meu irmão". Havia um esquema pelo qual o parentesco integrava o escravo na tribo. Isso porque os Kadiwéu tinham praticamente substituído o pacto pela adoção, uma vez que as mulheres não se permitiam ter filhos. Esta é uma característica dos grandes povos guerreiros, onde as mulheres se tornam guerreiras também e se negam a ter filhos.

Há toda uma história longa do contato desses índios com a civilização que me interessou muito e, com base nela, publiquei, mais tarde, minha monografia principal sobre eles. Nesse tempo todo, eu vivia mais da metade do ano com os índios e menos da metade do ano aqui no Rio. Geralmente, me preparando para a próxima viagem e organizando o material. Essa era minha vida durante a época vai de 1946 a 1948.

\section{E depois disso? O Sr. não voltou mais para os Kadiwéu. Que rumo tomou sua carreira?}

Em 1949 eu me dei outra tarefa etnográfica. Ocorre que eu estava empolgado com a minha carreira de antropólogo, e ocorre, ainda, que meu livro sobre religião e mitologia Kadiwéu ganha o premio científico-literário mais importante do Brasil. Era o prêmio Fábio Prates que se dava em São Paulo e tinha grande repercussão. Foi muito importante para mim porque até àquela época minha família achava que eu era um boêmio e não acreditavam que eu tivesse feito uma carreira. Quando ganho o prêmio e sai nos jornais principais de Minas, do Rio e de São Paulo entrevistas comigo, eles viram que não era só boêmia. E muito curioso que, pouco antes, a minha mãe tinha dito: "Meu filho fala com seu tio deputado, arranja um outro emprego, você está 
muito sacrificado.” E eu disse: "Mas mamãe, eu gosto muito do meu emprego, estou muito bem.” Ao que ela respondeu: "Não meu filho, esse emprego de amansar índios é muito pesado.” Ela achava que eu era um amansador de índio! E o prêmio Fábio Prates foi importante na minha carreira porque o livro tinha sido publicado, havia uma concorrência muito grande, foi importante para mim pessoalmente, como afirmação, e foi importante para os meus amigos e minha família porque, de repente, eu reapareço como um homem inteligente, realizado, ou qualquer coisa assim.

Nessa época, por volta de 1949, eu estava me preparando intensamente para estudar outro grupo. O meu ideal, agora, era procurar um grupo o mais parecido possível com os Tupinambá de 1500, porque foram eles que fizeram a forma básica da cultura brasileira. O Brasil é uma variante da cultura Tupinambá, com eles nós aprendemos a caçar, pescar, cultivar o que cultivamos. Teria sido impossível o europeu desembarcar aqui com a técnica de viver em Portugal se não tivesse essa herança indígena adaptativa. Por outro lado, a nossa carne é feita de Tupinambá também. O brasileiro é produto de uma mulher Tupinambá, prenhada por um europeu e que tem um filho, que alguns vieram a chamar de mameluco, que não se identifica com a mãe indígena. Esta é uma inimiga cativa de raça inferior, que não está em situação de igualdade com o pai. Então, o fruto dessa união é o brasileiro, que leva geneticamente a marca indígena e que dá a toda população brasileira um ar indígena. Então o Tupinambá é extremamente importante para o Brasil. Eles eram os índios que o Florestan estudava em papéis, os dos excelentes cronistas do século XVI, que foram descritos com muito detalhe, não só a antropofagia, os ritos, mas o modo de ser. Então o que o Florestan fazia com papéis eu queria fazer com uma tribo. Aparentemente, o grupo mais próximo, seria o dos índios chamados Urubus, mais tarde descobri que a autodenominação deles era Kaapor, o que é praticamente silvícola, porque "kaa" é mata e "por" é morador, ou seja, "gente da mata”. Depois se viu também que, no plano lingüístico eles mantinham certa semelhança com os Tupinambá, embora passados quinhentos anos e vivendo a doida desventura de serem enxotados pela civilização, por milhares e milhares de quilômetros. E claro que eles não tinham nenhuma semelhança formal, mas eu iria descobrir, depois, que tinham muitas outras semelhanças, apesar do tempo passado e das vicissitudes sofridas. Se nós não somos os mesmos que éramos em 1500, eles são menos ainda.

$\mathrm{O}$ fato é que eu havia me preparado longamente para aquela pesquisa e, finalmente, fui a campo para uma primeira pesquisa de vários meses. Subindo 
o rio Gurupi que corre do Maranhão ao Pará, trabalhei na margem maranhense. Esta primeira expedição àquela área foi muito desastrosa, porque encontrei os índios atacados por um surto de sarampo. A população decresceu terrivelmente, eles emagreceram enormemente. Foi uma época muito infeliz, ainda assim eu encontrei algumas aldeias intocadas, onde existia uma grande alegria de viver, o que me deu uma idéia do que era a beleza da vida daquela gente.

\section{Foi durante esta viagem que o Sr. produziu o filme sobre os Urubu-Kaapor?}

Foi. Pude realizar ali, com Heinz Foerthman, um cinegrafista que eu tinha levado, um filme de uns quarenta minutos sobre um dia de vida de uma tribo da floresta tropical. O que eu desejava, mesmo, era ter feito toda uma documentação cinematográfica de tudo, mas havia duas coisas: primeiro, a metade da tribo tomada pela epidemia, e num estado de prostração terrível; segundo, eu peguei a época das chuvas, então chovia torrencialmente a semana inteira. Ficava-se dentro da casa e chovia e chovia. Havia muita fome, muita penúria. Quando chove, os rios enchem, então fica impossível pescar, porque quando há água demais os peixes dispersam. E é impossível também deslocar-se muito para caçar. Então falta carne de caça, falta carne de peixe, vive-se do que tem nas roças: é muito penoso. E quando isso melhorou, nós pudemos ainda fazer um filme que ganhou um prêmio de melhor filme etnográfico do Museu do Homem, de Paris. Mas esse filme foi o resumo do que nós pensávamos, porque eu imaginava um filme com toda uma documentação copiosa, de todos os costumes, de tudo, e resultou naquilo que foi praticável. O bom deste filme é que ele não mostra o índio no dia de festa, não mostra 0 índio enfeitado, mas o índio tal como ele é no dia-a-dia: quando vai na roça com a mulher, vai caçar, vai coletar fruto da mata, como prepara as coisas. Há seqüências muito bonitas de como se faz uma flecha. Aliás, quando a gente olha para uma flecha indígena, parece uma coisa simples, mas não é. A flecha tem que ter uma absoluta precisão de peso para que ela possa voar, ela precisa ter as duas plumas colocadas de forma exata para que ela se mantenha na rota certa, ela tem que ter uma ponta dura inserida num corpo muito leve, e essa inserção é uma obra de arte; além disso é preciso fazer com que uma madeira densíssima se combine com o caniço. Então, o filme mostra muito bem a elegância e a técnica de fazer uma flecha. E era muito curioso porque, para um índio, eu não podia dizer que estava filmando. Tinha uma máquina lá, mas ele não sabia o que era aquilo, ele ia fazendo a flecha, chegava certo momento e 
eu dizia: "pára um pouquinho", mas ele não queria parar e continuava fazendo a flecha. Eu tinha que esperar ele chegar naquele ponto novamente para continuar filmando. Então muitas flechas foram feitas ali e, da combinação delas, eu fiz uma síntese. E as coisas em geral são assim.

Depois dessa expedição longa, no ano seguinte, eu voltei a essa tribo, porque não estava satisfeito com o que sabia deles. Eu queria conhecer todas as aldeias e fiz uma coisa muito louca. Na primeira viagem eu subi durante vinte dias a remo pelo Rio Gurupi, entre o Maranhão e o Pará. Da segunda vez, subi pelo rio Pindaré, fui até o local onde havia marcado, com antecedência, de me encontrar com um grupo de índios e com o João Carvalho [Sertanista da Funai] também. Os índios tinham uma idéia de quando seria essa data, e enquanto isso, fui para diferentes aldeias. Quando cheguei no local e data combinados, fiquei muito nervoso porque eles não chegavam: passou um dia, uma semana, dez dias, vinte dias de erro! Ora o que são vinte dias de erro para um índio? Depois de vinte dias, finalmente, chegaram todos, contando as aventuras durante a travessia de quinhentos quilômetros para chegar onde eu estava. Passamos poucos dias ali e retomamos a marcha. Aí ocorreu a coisa mais terrível da minha vida: é que eu tinha comprado, no Maranhão, umas meias que tinham uma costura no meio do pé. Olhe, nunca compre uma meia com costura no meio do pé! Essa meia me fez um mal danado porque me arrebentou o pé dentro da bota. O que saia era uma água, não sangue, uma espécie de soro, era uma coisa horrível. Marchar sobre essa bota foi horrível. Isso eu tive de fazer pelo seguinte: eu ia com os índios, fazendo uma travessia do rio Pindaré para o rio Maracaçu, mas acontece que, numa certa altura, os índios descobriram sinais dos índios Guajá. Esta era a tribo inimiga preferida para brigar e matar. Então eu fiquei no meio de um fogo cruzado: eles queriam me levar para matar Guajá, e eu tinha que tirá-los de lá. Foi uma situação muito difícil e a única saída que encontrei foi forçá-los a descer comigo e pegar a linha telegráfica de São Luís para Belém que passa por ali. Consegui convencê-los e, fizemos a marcha ao longo da linha telegráfica, o que foi horrível: a linha telegráfica exposta ao sol, debaixo da linha do equador, naquela altura, com um calor insuportável! Então, não só meus pés arrebentaram, como tinha de tentar alcançar o grupo que ia na frente com toda carga da expedição. Nunca fiz um esforço tão tremendo na minha vida como este de andar sobre meus pés. Eu me lembro que em uma ocasião, peguei um remédio da expedição, que era um analgésico qualquer que se usa para olho, e injetei no meu pé. Foi pior ainda, porque o meu pé adormeceu e eu sentia que andava sobre o joelho. Nunca numa expedição eu tive 
sofrimento tão tremendo como nessa travessia de quilômetros e quilômetros, primeiro pela linha telegráfica, depois pelo rio Maracaçu. E o pior é que eu subi até o último ponto deste rio por uma bobagem: os índios teimavam e eu não atendia. Acontece que o mapa que eu tinha era feito pelos norte-americanos durante a guerra, por aerofotogametria. Onde havia muita nuvem, eles inventavam um rio, e naquele rio que nós estávamos, eu cheguei até as nascentes dele e não tinha mais rio, mas eu teimava com os índios que, pelo mapa, deveria ter mais rio. Aquele rio, por um erro da carta geográfica, deveria encostar no rio Gurupiuna e dar nas aldeias que eu queria visitar.

Vinte anos antes tinha ocorrido a pacificação naquela área, até então os índios Urubu-Kaapor eram os índios mais aguerridos do Brasil e eram o pavor de toda aquela região. Foram pacificados, mas logo depois da pacificação foram contaminados com gripe e com varíola, morreram muitos. Um índio Orokó, revoltado, matou o funcionário principal da pacificação, do SPI, e mais outras pessoas também. O grupo que tinha feito contato com os brancos, não queria aquilo, então fizeram ostracismo, deixaram aqueles Orokó isolados. Perante os brancos, disseram que iam lá matá-los, mas nunca foram atrás, e eles viveram vinte anos isolados. Eu queria muito ver esses Orokó, porque os meus índios estavam em contato com os Tembé, e eu não sabia até que ponto os mitos deles eram mitos puros, ou mitos influenciados pelos Tembé, o que era Tembé e o que era Kaapor.

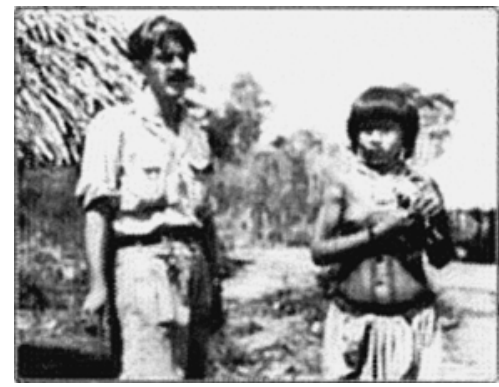

Darcy Ribeiro entre os Urubu-Kaapor (foto: arquivo Museu do Índio).

Mas os índios que estavam comigo tinham pavor de chegar lá porque achavam que eles iam me matar e iam matá-los. Eles não se visitavam e não sabiam também, com muita precisão, onde era. Num certo momento, por sorte, atravessando um lugar, os índios ficaram suspeitando do barulho que ouviram. 
Eu fui me aproximando com meu guia na época, o João Carvalho. Tinha um grande grupo de índios batendo timbó para intoxicar os peixes, era uma grande pescaria. Então, quando chegamos os índios ficaram espantados de ver chegar aquelas pessoas estranhas, mas deram uns peixes para assarmos e aí fiquei sabendo que aqueles índios eram Orokó. Saí dali e fui visitar a aldeia deles, na aldeia tive uma surpresa, eu esperava ver casas originais, sem influência da civilização, e o que eu vi foi um horror: eles tinham feito uma palafita, tal como tinham visto no Maranhão, onde as casas de palafita eram feitas no meio das plantações de arroz. Então, para mim, foi uma decepção. Outra coisa, eu nunca vi tanta barata, era um tipo de barata pequenina de $1 \mathrm{~cm}$, e havia uma epidemia dessas baratas. Eu acabava ficando mais no mato que na aldeia, porque no mato tinha menos barata. E lá, pela primeira vez, eu fui objeto de um estudo meticuloso: eles fizeram a minha anatomia completa, tocaram no meu corpo inteiro. Eu não sou muito peludo, e eles puxavam os pelinhos que eu tinha nas pernas, os pelos do sovaco, os pelos do púbis interessavam muito, o pau interessava muito. Olharam-me inteirinho, descobriram que eu tinha dentes de ouro, diziam que era dente de pedra e metiam a mão na minha boca. Outra coisa formidável é que a planta do meu pé, era delicada e eles pegavam e passavam a planta do meu pé na cara, porque eles nunca tinham imaginado um pé que nunca andou descalço, um pé despreparado para andar descalço. E de admirar, por exemplo, os índios correndo na mata para caçar guariba. Eles não olham por onde andam, aquele pé é capaz de suportar qualquer coisa. Mas o meu pezinho interessou muito. Interessou mais o meu cozinheiro, Cesário, que era preto, e, até então, eles tinham visto preto só de longe. Quando pegaram o meu cozinheiro de perto, levaram-no para banhar no rio, para arear e chateá-lo o tempo todo. Dali seguimos viagem, eu percorri as demais aldeias, ao longo de uns $800 \mathrm{~km}$, e completei a pesquisa com eles. Os resultados dessa pesquisa eu publiquei em muitos artigos, e estimulei mais gente a fazer pesquisa nestes mesmos índios.

Agora, nesse momento eu estou vivendo uma aventura muito especial, é que eu decidi tomar meus diários, que compõem umas seiscentas ou oitocentas páginas, passar para o computador e preparar para publicação. E interessante porque, em lugar de fazer uma monografia falando de parentesco, mitologia, arte, dilacerando a realidade, decide publicar como está: tudo misturado. E o que estou preparando, está sendo calmamente lido, para ser editado. Para mim é uma coisa muito bonita, porque, na medida em que leio, sou eu outra vez com vinte e poucos anos, lá, vivendo com os meus índios e revivendo aqueles momentos de que eu já tinha esquecido. Então, cada página para mim é uma surpresa. Este é 
um livro para ser publicado no futuro, não estou com pressa de publicá-lo, o que eu gosto muito é que eu encontrei a forma de dar sentido a isso.

Uma vez fui lá falar com o Lévi-Strauss e perguntei o que ele achou do meu livro $O$ processo civilizatório. Eu tinha mandado para ele a edição em inglês do Smithsonian, e ele disse: "me interessou”, assim com um certo muxoxo. O problema é que ele tem horror a qualquer interpretação diacrônica, e a questão dele é gramática, é tratar a cultura como se fosse língua, porque qualquer coisa que não seja gramatical, que seja diacrônica, horroriza-o. Mas aí ele me disse que eu era um dos príncipes da observação, que várias vezes ele tinha utilizado os mitos que eu colhia, o meu material etnográfico e que isso era o nobre que eu tinha. Eu me irritei e disse: "Então tá, eu sou o coletor de material de campo e você faz a interpretação teórica.” E ele respondeu: “Não, a minha obra teórica não vai durar vinte anos, nem a sua, mas a etnografia vai, porque todos os bons registros do século passado são sempre reeditados.” E eu tenho a sensação de que esses meus cadernos de campo devem ser publicados, porque isso pode interessar a muita gente.

Isso que eu falei até agora, é minha carreira de etnólogo, e eu fiz a minha carreira de etnólogo, como alguns outros fizeram. Eu me concentrei sobre dois povos, a respeito dos quais eu fiz monografias e estudos de profundidade. É claro que nesse período eu estudei outros, eu fui muitas vezes ao Xingu, fui muitas vezes ao Amazonas, ao Rio Negro, fui muitas vezes ao Araguaia, estudei os índios de São Paulo, os Kaigang, os Guarani, os Bororó. Mas nos doze anos em que me dediquei à etnologia, as minhas duas pesquisas básicas foram, cada uma delas, compostas de duas longas expedições, e o que vai ficar da minha obra de etnólogo para colocar ao lado dos outros antropólogos brasileiros é isso, minha contribuição. Se eu tivesse feito só isso, eu seria esse etnólogo assinalado, recordado, porque trabalhou pelo menos em duas tribos, com muita profundidade.

\section{E por que o Sr. não continuou realizando trabalhos de campo com outros grupos indígenas?}

Numa certa altura, ocorreu dentro de mim uma quebra, até então minha postura era lévi-straussniana, era aquela de recolher os fósseis do espírito humano, procurar o mito mais perfeito, mais antigo, mais arcaico. Já no meu livro sobre mitologia Kadiwéu, eu quebrei com isso, porque publiquei muito mito impuro sobre espingarda, sobre os brancos, etc.

Começou uma atitude mais profunda em mim de verificar que o etnólogo que vai ao encontro dos índios, vai ao encontro deles como quem vai ao encontro do primitivo, do arcaico e poucas vezes tem olhos para ver o índio presente, o destino dele. E eu comecei a ver que é muito mais explicativo para 
um grupo indígena, sua condição de distância, do que o grau de conservação de sua cultura. Foi então que eu inventei uma coisa que causou muita irritação nos antropólogos bestas: o "complexo de Berlim”. Na época, eu dizia que a ninguém ocorreria jamais, chegar em Berlim, em 1945, quando Berlim era bombardeada com uma quantidade de aviões diariamente, estudar a forma da família alemã ou estudar a literatura alemã, porque é evidente que nada era observável ali, senão aquela desgraça. E, no caso dos índios, é como se estivessem sob o bombardeio de Berlim, sob um bombardeio tremendo de enfermidade, de violência, do diabo; enquanto o antropólogo fica ali, querendo ver o que é o índio puro, subsumindo daquilo uma realidade outra sem valor explicativo. Na maior parte das etnografias que andam por aí, você pode ler uma inteira sem ver nada do que o índio está sofrendo, que a terra foi tomada, que a filha dele foi roubada, que a mulher dele foi estuprada, que ele é vítima de toda violência, porque só aparece o que interessa ao antropólogo que foi lá.

Então essa foi uma mudança muito profunda na minha atitude, e uma mudança que acabou fazendo com que eu me afastasse da etnologia de campo. Fui fazer outra coisa e me converti num combatente da causa indígena. Desde então eu, no mundo inteiro, fiquei conhecido como um lutador pela causa indígena. Nesse sentido, é que eu costumo dizer que os índios me deram muito mais do que eu dei a eles, eu ajudei a fazer o Parque do Xingu, eu nesses anos todos lutei muito por eles. Mas o fato é que através de tudo isso eu ganhei renome internacional e uma respeitabilidade que eu não teria alcançado se não tivesse essa atitude de amizade com eles. De fato, eles me deram mais do que dei a eles.

Essa mudança de atitude teve também consequências laterais curiosas, uma delas é que, eu consegui transformar o que era a seção de estudos do SPI e do Conselho de Índios, onde eu trabalhava, num prédio novo que veio a ser o Museu do Índio. Isso teve muita repercussão, porque foi o primeiro museu do mundo feito contra o preconceito. O museu era feito para as pessoas chegarem lá e mudarem de atitude para com os índios. A experiência diária do museu era pegar crianças de quarta série primária mais ou menos, nas várias escolas do Rio, mandar escrever sobre "O índio”, antes de ir ao museu, e escrever novamente, na volta do museu. A comparação das duas descrições era uma beleza. Dava para ver o trabalho bonito que o museu fazia mudando atitudes em relação ao índio. Na escadaria da entrada do museu, o visitante se deparava com uns quarenta retratos de índio sorrindo. Já aí quebrava aquela imagem do índio feroz, comedor de gente. Era um índio sorrindo, índio beijando criança. Então isso contribuía para mudar atitudes. Depois, mostrava-se a beleza da 
arte plumaria, a delicadeza das cores. Tinha, também, um painel muito grande em que eu dizia que os índios tinham domesticado quarenta plantas importantes, como milho, mandioca, amendoim, abacaxi, etc. E que nós, brasileiros, por exemplo, não domesticamos nenhuma, e mostrava as dificuldades de uma roça indígena, mostrava uma floresta original, as dificuldades de abater uma floresta com machado de pedra que não corta, que esmaga, e apesar disso, a grandeza da agricultura indígena, que é equivalente à agricultura oriental. No Tigre e Eufrates se desenvolveu uma agricultura de grãos que fez a civilização, e aqui, foi uma agricultura de tubérculos e de frutos tropicais que fez isto. Então o Museu do Índio teve muita repercussão no Brasil e fora. Mas essa é a época em que eu saio e crio, no museu, ainda o primeiro curso brasileiro de pós-graduação em antropologia. Não havia mestrado, nem doutorado no Brasil e eu só vim a regulamentar isso na Universidade de Brasília. Aquele era um curso muito intensivo em que cada aluno tinha um ano de estudo em tempo integral, orientado por pessoas com nível de doutorado, e depois fazia um ano pesquisa de campo e mais um ano de elaboração da pesquisa. Era um programa de três anos destinado a formar pesquisadores.

Nessa época eu entro em conflito com o Serviço de Proteção aos Índios. E eu acabei saindo de lá, porque o conflito era aberto. Eu queria que o Serviço não tivesse a atitude burocrática que tinha e tivesse uma compreensão mais profunda. Mas era uma guerra também contra os antropólogos que queriam ler no índio a natureza humana como eu queria, como eu fiz também. Mas foi uma crise que eu tive no meu espírito e também tive com o mundo quando eu mudei de atitude.

Resulta aí, que me aproximo do Anísio Teixeira que era um grande educador, um homem que orientava o Ministério da Educação, como educador. Eu me aproximo dele, nós nos tínhamos muita antipatia um pelo outro. Nós tínhamos muitos amigos comuns também e Anísio sempre dizia que eu era uma pessoa meio louca, que sendo uma pessoa muito competente como é que eu me dedicava a $0,002 \%$ da população brasileira, no lugar de me dedicar a toda a população brasileira. Era uma espécie de brincadeira que fazia, mas o certo é que eu passei a trabalhar com ele e rapidamente passei a ser o vice-diretor de um grande instituto de estudos educacionais, e levei o curso para lá. Ou seja, o Centro Brasileiro de Pesquisas Educacionais, que passei a dirigir no plano científico. Eu levei aquele curso de aperfeiçoamento em antropologia e em ciências sociais e funcionou muitos anos ali. Esse curso é que depois passou para o Museu Nacional, com Roberto Cardoso, e que continuou funcionando e funciona até hoje. Mas eu me lembro de que naquele período, de transição, 
houve uma transição também nos meus interesses. Aproximando-me da educação, com Anísio, eu passei a me interessar por educação primária, a fazer um programa de pesquisas, o maior que o Brasil teve, um programa de trinta e tantas pesquisas antropológicas e sociológicas em que eu tentava entender culturalmente e socialmente o Brasil, para termos um discurso melhor sobre a educação no Brasil. Para saber como educar, como fazer o Brasil entrar na civilização letrada. Então foi um programa de pesquisa muito ambicioso em que eu chamei os principais cientistas sociais brasileiros para cooperar neste programa, estudando temas diferentes. Eram estudos tanto do Brasil provinciano, quanto do Brasil urbano. Inclusive eu fiz 14 pesquisas em cidades representativas de áreas brasileiras em que eu estudava a cidade e o seu contexto rural. Essas pesquisas tiveram muito êxito e foram publicados 14 livros. Logo veio a ditadura.

Nessa época eu já estava com a vida alterada, porque tinha sido chamado a ser ministro da Educação. Depois fui ser chefe da Casa Civil, que é o segundo cargo do governo no Brasil: é como ser primeiro ministro. Eu dirigia a campanha pelas reformas de base, principalmente a reforma agrária, a reforma urbana, a reforma contra o capital estrangeiro, e foi uma luta muito grande em função da qual fui parar no exílio.

Agora vou a outro capítulo. Quando a gente fica velho tem que falar um pouco de si mesmo, para os jovens saberem. E assim de improviso, você se lembra de algumas coisas e se esquece de outras. É bom, porque é uma seleção. Bom, derrubado o governo, eu me vi no exílio. Nos primeiros meses no exílio eu estava num desespero tal que o que eu fiz com o Brizola e com o grupo dele foi imaginar alguma forma de retomar o poder, mas isso me ocupava pouco tempo: enquanto eles ocupavam as 24 horas do dia pensando em fazer alguma guerra, eu lia ciência e ficção. Eu li tudo o que pude pegar sobre ciência e ficção. Eu li uma centena de livros, que era um modo de fugir da realidade que estava ali. Então aquilo é que alimentava o meu espírito.

Mas depois de alguns meses, uns três meses, eu caí em mim. Na primeira semana eu já fui contratado pela Universidade como professor de antropologia e depois comecei a fazer um programa de reforma universitária. Aí eu voltei a manter uma vida intelectual mais intensa porque eu me propus um velho problema da minha vida: Por que o Brasil não deu certo? Ainda não deu certo? Por que outra vez a direita nos derruba? Por que não fomos capazes de defender as reformas que estavam quase alcançadas? Por exemplo, a reforma principal, que era dar um pedacinho de terra a dez milhões de famílias brasileiras? Era uma coisa factível nesse país imenso com essa quantidade enorme de 
terras. E quem dirigia isso era o Presidente, que era, ele mesmo, um latifundiário, mas compreendendo que, se milhões de famílias tivessem terra para plantar o que comem, para se manter ali, seria uma forma de fixá-las no campo e de que seus filhos tivessem educação. Eu me pergunto: Por que fracassamos? E escrevi então um livro sobre o Brasil. Um livro de quatrocentas páginas. Em um ano eu escrevi esse livro que seria a síntese daquelas pesquisas que eu tinha feito, das quais eu tinha catorze livros escritos e muitos manuscritos também. Mas depois, ainda que fosse síntese de estudos originais, ao fim do livro, quando terminei, verifiquei que o livro não dizia nada de novo. Dizia o que estava em outros livros também, porque não havia uma teoria sobre o Brasil. O Brasil, de fato, era inexplicável, porque as teorias existentes não explicavam o Brasil. E eu vi que era necessário fazer uma teoria.

Então eu joguei de lado aquele meu livro, para fazer uma teoria explicativa sobre o Brasil, que me permitisse escrever um livro mais compreensivo. Nessa época há uma crise no pensamento filosófico mundial, e particularmente no marxismo. São publicados os Grundrisses do Marx, os borradores do Marx, que é do Marx maduro, texto de 1845, e é incrível que a teoria implícita sobre a formação da sociedade ou do capitalismo era muito melhor que a do Engels, que tinha se inspirado no livro de Lewis Morgan: Aorigem da família, da propriedade privada e do Estado, que é uma má etnografia, mas era um esforço de compreensão das sociedades como coisas explicáveis e como capazes de evolução.

Engels se encantou com o livro do Morgan, e o Marx preferiu calar as teorias dele. Mas, quase um século depois, as teorias do Marx são publicadas e, de repente, o marxismo tinha duas teorias sobre a origem das sociedades, e quem tem duas não tem nenhuma. E a discussão estava reaberta. Isso teve um grande efeito sobre mim que procurava uma teoria explicativa. Um antropólogo norte-americano pode ficar contente com a explicação do passado dele na Europa. Ele esteve na Europa romana e foi romanizado ou quase romanizado. Um francês também pode entender as coisas assim, porque o seu passado é um passado primitivo, depois escravista, depois feudal. Aquele é o passado dele, mas não era o nosso passado! Não era uma teoria aceitável, e as teorias do Marx sobre a sucessão das sociedades eram muito mais inteligentes e muito melhores do que a que havia. E eu fiquei encantado com as novas teorias do Marx porque é como se eu tivesse levantado a pedra tumular e dito outra coisa do que se dizia dele, por exemplo, sua compreensão de que houve uma formação anterior ao escravismo e à sociedade arcaica que era a formação de grandes estados como o Egito, a Mesopotâmia, como México, como o Estado 
incaico. Era a compreensão de um tipo de sociedade não escravista, mas capaz de se organizar em bases diferentes, em geral, sociedades hidráulicas, sociedades que faziam utilização de águas e.de irrigação e que permitiam grande produção agrícola e portanto um excedente para fazer grandes obras.

Isso não aparece nem em Engels, nem em Morgan. Para Marx, havia outra sociedade anterior a escravista: os judeus nunca foram escravos do Egito, senão nunca teriam saído de lá. Eles saíram porque eram vassalos, estavam lá ligados a tarefas e depois de cumprirem essas tarefas foram despedidos. Isso é totalmente diferente da escravidão pessoal, que há na Grécia, depois em Roma, em que se escraviza a pessoa individualmente, a destribaliza, a desagarra de seu povo, e faz dela um objeto que tende a ser totalmente transformado. E que dá um tipo de sociedade diferente, em que a forma da família muda porque a propriedade é individual, é familiar. Então isso tudo era muito mais claro nos textos de Marx.

$\mathrm{E}$ eu, como o mundo inteiro, ficamos encantados com isso. Tentei, então, fazer alguma coisa que nos tornasse explicáveis. Evidente que mesmo as teorias do Marx eram inexplicáveis para a Península Ibérica, como eram inexplicáveis também para a situação árabe, porque estas não eram sociedades feudais, não eram capitalistas, não eram socialistas. Haviam mais formações do que se considerava, e no caso específico da Península Ibérica, Marx nunca entendeu como é que Portugal e Espanha são capazes de, num certo momento, se expandir e criar um mundo só, fazendo do universo inteiro um só mercado, fazer essa expansão extraordinária.

Essa expansão podia ser obra do feudalismo? Jamais. O feudalismo é uma sociedade talhada pela autoridadezinha local que só se interessa pelo castelo, pelas imediações do castelo. O capitalismo só surgiria quase um século depois, na Inglaterra e na Holanda. Então, havia uma formação ali que não era capitulável nas coisas que existiam e que eu queria compreender, que seria algo parecido com a civilização árabe. Então, eu escrevi o meu livro, O processo civilizatório que é uma tentativa de compreender dez mil anos da história humana, genericamente, mas dez mil anos de história, de forma tal que não só a Península Ibérica, não só o mundo árabe, mas nós mesmos também pudéssemos ser compreensíveis.

Era mais legítimo que um brasileiro fizesse isso, ou um latino-americano, que qualquer outro, porque nós tínhamos conhecido sociedades tribais arcaicas, sociedades coloniais, nós tínhamos vivido tipos de sociedade diferentes. Nós tínhamos uma massa de informação maior do que qualquer teórico europeu ou qualquer filósofo de outro lugar. E então, realmente, eu aceitei a ousadia de 
escrever uma teoria da história, baseado na idéia de que, com base no desenvolvimento da tecnologia, se podia fazer uma seriação da sociedade, melhor do que as seriações que existiam. Fui muito ajudado nisso pelos arqueólogos, graças à Betty Meggers, que é uma arqueóloga muito amiga minha a vida inteira. Eles me ajudaram a estabelecer pautas das tecnologias e a correlacionar as tecnologias diferentes e a mudança das tecnologias com a mudança das civilizações.

\section{Como foi a repercussão da publicação deste livro?}

Teve muita repercussão. Eu me lembro bem que quando mandei o livro para ser publicado aqui no Brasil, um intelectual conhecido meu dizia: "O Darcy é maníaco, quem é ele para escrever uma teoria da história?” Quer dizer, é esse complexo de inferioridade do brasileiro que o leva a pensar que ele é incapaz de fazer uma teoria da história. Então, ele escreveu uma carta sobre isso e o editor me mandou. Aí eu mandei para ele a edição norte-americana, para mostrar que a editora mais importante do mundo em antropologia, que é a Smithsonian, de Washington, publicou meu livro. Eu disse para meu editor: "Não seja besta! Você não publica porque é imbecil! E eu proponho que você publique o meu livro e a carta desse idiota lá também. Porque você pode publicar o meu livro como tradução da edição norte-americana.” Depois dessa edição saiu uma outra na Alemanha, onde o livro foi muito discutido.

É um livro latino-americano, brasileiro, escrito no Uruguai, com muita ajuda de antropólogos e arqueólogos de fora, que teve um grau de discussão internacional muito grande. Há uma revista antropológica muito importante, que é Current Anthropology, que uma das coisas que faz é entregar a uns dez antropólogos um livro ou um artigo importante para que eles leiam e façam apreciações, e o meu livro foi objeto de apreciação internacional.

Esse livro, O processo civilizatório, afinal saiu em uma edição brasileira também e tem uma dezena de edições nas línguas principais. Mas o tipo de explicação que eu alcançava no Processo civilizatório era muito genérico porque eu tinha que explicar dez mil anos, em poucas palavras, era uma coisa muito genérica, como as teorias de alto alcance histórico. Todas as teorias francesas da história são muito genéricas, e eu sentia necessidade de alguma coisa mais concreta.

\section{O que o Sr. fez então?}

Então eu parti para escrever uma outra coisa, que era um livro que, em vez de alto alcance histórico, tinha médio alcance. Eu o chamei de As Américas e a civilização. Neste livro eu examinei quinhentos anos da história americana para explicar as causas de seu desenvolvimento desigual: por que o Brasil, que era e 
fora muito mais rico, muito mais ilustrado do que os Estados Unidos, ficou para trás? Os Estados Unidos eram o próprio atraso. Nunca tiveram cidades como Salvador, como Recife, como o Rio, muito menos como Ouro Preto, nunca tiveram nada de civilização. E nós tínhamos muito mais e tínhamos muito mais riqueza também, porque nós éramos muito ricos. O Haiti também, que era a pérola da França, que tinha uma gente paupérrima. A França vivia do Haiti e a América do Norte vivia de vender comida e artefatos para o Haiti, mas aquela gente paupérrima progrediu formidavelmente e se organizou como civilização. E nós, que éramos muito mais ricos, e no caso do Brasil, muito mais ilustres, caímos no atraso. Por quê? Quais as causas do desenvolvimento desigual?

Neste livro eu faço uma tipologia dos povos americanos, em que eu mostro que os povos americanos podiam ser classificados numa categoria de "povos testemunho", que eram povos que viviam o drama de ser dois. Este é o caso dos povos do altiplano andino, e do México, da Guatemala, em que a civilização moderna e européia, chega lá e se implanta, mas a gente de lá continua carregando no peito uma outra alta civilização e outros altos valores. Poderia se dar mil exemplos, como quando eu organizei o Memorial da América Latina e levei um grupo para o México e a Guatemala, para fazer uma grande coleção de artefatos de lá. Nessa ocasião, eu e os outros pudemos ver a quantidade de sabedoria e de beleza que você encontra naquela população aparentemente primitiva, como a da Guatemala ou do altiplano andino, que tem um sistema de cura e de fórmulas que você encontra também nos remanescentes de altas civilizações como a civilização árabe, como a chinesa, como a indiana. Eles são o que eu chamo de "povos testemunho", porque guardam em si a memória viva das altas civilizações que eles foram.

Outra coisa são os "povos transplantados”. Povo transplantado é gente européia que vai para o espaço do além-mar, tira os índios, limpa o terreno e ali faz uma sub-Europa. É o caso, do progresso da Austrália em relação ao Brasil. A Austrália, cem ou duzentos anos mais jovem. Ora, não tem novidade nenhuma fazer a Austrália é uma bobagem! Você pega um pocadinho de irlandeses, escoceses, italianos e joga lá e eles fazem uma Inglaterra de segunda e aquilo ali funciona muito bem. E totalmente diferente do que pegar massas de índios, de negros, de europeus e construir um gênero humano novo, construir uma civilização. Então, nesse livro eu apresento as categorias de "povo testemunho", de "povo transplantado", e de "povo novo", que é povo que surge como gênero humano novo. E o caso específico do Brasil, da Venezuela, da maior parte dos países da América Latina, em que a população 
foi desindianizada. Desafricanizaram o negro, que aqui posto foi refeito, e deseuropeizaram o europeu. Então esse “povo novo” não está pregado em passado nenhum, nem está reproduzindo civilização estranha nenhuma, ele é um gênero novo, é uma coisa nova, uma gente que se vê de repente, que é o chamado mameluco, que não é índio, porque não se identifica com a mãe que o pariu, e cuja cultura ele comeu, não é aceito pelo pai como igual também, é um mulato, não é africano, evidentemente, e também não é indígena, e não é europeu. Essa gente, que não é ninguém e que se constrói, a si mesma, como uma outra entidade, é um gênero humano novo, alguma coisa nova no mundo.

\section{E esse livro, calcado num escopo de tempo menor e voltado a enten- der a gênese de um continente, o satisfez?}

Não. Eu ainda não estava insatisfeito porque, no fundo, não havia teorias explicativas aceitáveis para coisas tão importantes como uma tipologia das classes sociais, não havia tipologia das formas de ação política também, não havia também um estudo adequado das forças insurgentes, das esquerdas, ou das forças capazes de uma revolução. E não havia uma teoria adequada também da cultura, da nossa cultura, feita de retalhos, tomada de tantas matrizes diferentes, mas fundida e que chegou a ser uma coisa original e própria. Então eu escrevi um livro de verdade sobre a América Latina, em que eu proponho uma tipologia das classes sociais, que não foi essa bobagem de estar repetindo a conversa marxista de proletariado e aristocracia e burguesia que eu não vi aqui. Esse livro é $O$ dilema da América Latina.

Tendo escrito esses livros, escrevi mais um que é Os índios e a civilização, que eu vinha fazendo há anos, por encomenda da Unesco. Este livro me ensinou muito porque me fez desenvolver um conceito de "transfiguração étnica”, que é o processo pelo qual os povos se fazem e se transformam ou se desfazem. Nenhum índio vira civilizado, o que há é que um povo indígena, mantendo sua indianidade, vai morrendo e, ao lado dele, surge um núcleo humano que cresce à custa dele e que cresce contra ele, que é o núcleo civilizado. Então, assim como não há conversão, não há assimilação. O que há é uma integração inevitável. Se o índio é cada vez mais cercado de um contexto civilizado ou comercializado, se ele próprio se converte em mão-de-obra, se ele próprio tem que produzir mercadoria, é claro que ele tem uma integração cada vez maior com a sociedade nacional. Mas esta integração não quebra nele a identidade, que é como a do judeu, como a do cigano. Ele mantém a sua identidade como indígena. Apesar de transformados os costumes, apesar de mudar o modo de se vestir. Apesar de todas essas mudanças, ele permanece indígena. Então, eu chamei a isto, teoricamente, processo de 
transfiguração étnica. A transfiguração étnica se faz através de instâncias, que não precisam ser uma depois da outra. São instâncias nas quais um povo se transforma e se transforma tanto mais, necessariamente, porque é transformando-se que ele sobrevive. E ele se transforma mantendo sua própria cara, mas mudando para tornar viável sua vida num contexto que lhe é hostil.

Num primeiro momento, ocorre um tipo de interação biótica: chegam os brancos trazendo suas pestes. O mundo antigo, Europa, Ásia, África, estava integrado e as suas pestes passavam entre eles. Um povo que não sofreu as pestes, como os povos americanos, morria pela metade quando chegava o europeu com suas doenças. Quando, então, chegava a segunda doença, ela matava a outra metade. Ainda hoje, as tribos que estão entrando em contato com a civilização sofrem também o mesmo processo. E um processo de interação biótica em que duas populações, bioticamente diferentes, se encontram e a coexistência entre elas provoca este desastre. No caso do Peru, por exemplo, a população caiu incrivelmente, muito menos em decorrência da guerra e da escravidão que também matam muito, mas em função deste tipo de interação biótica. A relação é de 1 por 25: onde existiam 25 pessoas, depois de um século, você tem uma pessoa.

Assim, a transfiguração étnica se dá, primeiro, por uma interação que é biótica e, depois, uma interação ecológica. Se você coloca vacas e cabras e porcos, onde os índios estavam, onde eles faziam suas roças, esses animais tomam o lugar onde eles estavam e provocam enorme mortalidade. E claro que se considera uma vantagem que os europeus tenham trazido animais domésticos, mas esses animais representam uma invasão no ambiente e impõem uma nova condição ecológica, fazendo com que as populações diminuam enormemente. É importante entender isto porque o mundo moderno, vamos chamar o terceiro mundo ou o quarto mundo, cheio de miséria, de pobreza, é obra do homem europeu. O bandido europeu, onde ele chegou, encontrou povos tribais que eram ecologicamente equilibrados, produziam o que comer, tinham uma grande alegria de viver. Esses povos foram ecologicamente dizimados, na medida em que chegaram os europeus e passaram a usá-los como mão-de-obra e modificaram totalmente o ambiente deles.

Depois da interação biótica e ecológica, você tem a interação econômica, em que o índio é tomado ele mesmo e escravizado ou ele tem que entrar num circuito econômico, produzindo mercadoria. E depois tem ainda toda a esfera terrível da interação social, cultural, psicológica. Aí chega mais gente com convicção de que o único deus é o seu, de que o deus é branco, e mete isto na cabeça daquela população que tinha outras concepções. Todo o desprezo que 
o europeu tem pelos índios, se introjeta, sobretudo nas crianças e nos jovens, que passam a ver a si mesmos como um povo de segunda classe. $\mathrm{O}$ efeito deste processo de transfiguração étnica é, nessas várias instâncias, dizimador. Um povo vai desaparecer em qualquer destas instâncias, ou na primeira ou na segunda, ou pelo conjunto delas, ou pode sobreviver a elas.

Sobreviver a ela é se reinventar. Com essa compreensão que eu tinha alcançado, eu comecei a escrever este livro, Os índios e a civilização. É um livro que apresentava uma teoria nova, importante. Esse livro me custou muito trabalho para fazê-lo e eu custei muito a aceitá-lo. Eu publiquei quase todo o livro em artigos, que tiveram muita repercussão, porque foram publicados em muitas línguas. Mas só no exílio é que eu terminei-o como parte desse conjunto: O processo civilizatório, As Américas e a civilização, Os dilemas da América Latina e Os índios e a civilização, em que eu examino em detalhes do que aconteceu com as populações indígenas, com mais atenção sobre o século $\mathrm{XX}$, onde mostro que 80 povos desapareceram. Isso tudo me ajudava a fazer uma teoria do humano e uma teoria explicativa da sociedade brasileira.

Nesse livro, Os índios e a civilização, o senhor apresenta o modelo da "transfiguração étnica”, segundo o qual os grupos indígenas perderiam gradativamente seu patrimônio original, mas permaneceriam sendo identificados como índios, no sentido de “índio genérico". Passados mais de trinta anos da primeira publicação deste livro, como o Sr. vê a aplicabilidade desse modelo diante da questão indígena contemporânea?

É um pouco complicado. Esse livro eu comecei a fazer e, só depois de dez anos, publiquei no exílio. Antes, porém, havia publicado quase todo em artigos esparsos. O que ocorre é o seguinte, a Unesco decidiu fazer, na década de 50, uma série de pesquisas no Brasil, tomando-o como um país exemplar. Então contratou Florestan Fernandes, de São Paulo, Fernando Henrique ajudou um pouco também, e alguns outros. O objetivo era estudar o negro em São Paulo, como Charles Wagley e Thales de Azevedo tinham feito na Bahia e o Luiz de Aguiar, no Rio de Janeiro. Com isso a Unesco queria mostrar um caso de democracia racial, a partir de um país que tinha conseguido uma coexistência entre branco e negro, sem preconceito. Mas essa pesquisa foi uma decepção, porque em todos os lugares, os pesquisadores detectaram preconceito na forma de uma discriminação cruel, perversa, tremenda. Então foi o contrário do que havia sido previsto. Mas foi muito bom para o Brasil, porque acabou-se com aquela ilusão criada pelo Gilberto Freyre. Nessa ocasião, eles pediram a mim uma pesquisa paralela, também ideal. Havia a idéia de que o Brasil tinha conseguido que os 
índios virassem brasileiros, que os índios tornavam-se civilizados. E eu já levava em mim uma dúvida profunda sobre isso, influenciado por aquele caso Terena que comentei antes, em que o ponto de chegada não era tornar-se brasileiro, ele continuava Terena, vivendo na cidade, sendo tido como índio e se vendo como índio. Minha experiência com índios, no Brasil inteiro, indicava uma coisa diferente. E eu aceitei o encargo, dado pela Unesco, através do Alfred Metraux, de fazer um estudo em conexão com Marwin Harris e com Charles Wagley. Eu acabei escrevendo uma primeira forma reduzida do relatório que foi publicada por Marwin Harris e Wagley, e continuei trabalhando no material que, só anos depois, publiquei como livro com o nome de Os índios e a civilização.

Eu creio que nunca se fez uma pesquisa tão aprofundada e tão minuciosa. Eu contava com os arquivos do SPI e reconstituí todos os contatos de povos indígenas com a sociedade brasileira no século XX até aquela época. Então, de um pouco antes de 1900 até 1957 eu examinei o que aconteceu com estes povos, examinei todas as listas, como a do Capistrano, de lugares onde existiram povos indígenas e que agora eram aldeias ou cidades.

A teoria básica da historiografia brasileira era a de que os índios vão ficando civilizados e, num belo dia, o que era uma aldeia, vira uma vila. Eu desconfiei que não era assim e comecei a trabalhar para demonstrar isso, ou seja, o que acontece é que um grupo indígena que vive num certo local vai desaparecendo, vitimado por uma quantidade de elementos do contato: a peste branca, a doutrinação missionária e tanta coisa mais. Eles vão diminuindo, diminuindo, diminuindo, enquanto simultaneamente uma população vai crescendo ao lado, crescendo inclusive com carne dos índios. O brasileiro é feito, fundamentalmente, de uma mulher indígena prenhada por um branco, ou de uma negra prenhada por um branco. Aquele mameluco e esse mulato que não são nada, não são índio, não são africano é o que veio a ser o brasileiro. Agora, o fato é que, essa construção cultural é uma construção nova, é um povo novo, é alguma coisa que surge não como continuidade da vida indígena. O requisito para que uma tribo indígena permaneça ela mesma, é que os pais criem os filhos na sua tradição e, assim, o povo continua, a identificação étnica continua. E uma identificação, às vezes muito leve, como a identificação do judeu ou do cigano. O que faz do judeu um judeu e do cigano um cigano, é uma auto-identificação moral. O que faz do índio, índio, é uma identificação como tal. Por exemplo, quando eu cheguei do exílio estava o Geisel aqui querendo promulgar uma lei de emancipação. Ele dizia: "Se eu, até os doze anos só falei alemão, se sou tão bom brasileiro que sou presidente da República, por que esses índios teimam em 
continuar índios?” Ele queria obrigar os índios, por lei, a deixar de serem índios. Quer dizer, tomar as terras deles, pôr para fora, e isso é uma coisa de uma violência atroz. A primeira campanha que eu fiz no Brasil, quando voltei do exílio foi contra essa lei do Geisel, essa loucura do Geisel.

Mas o importante da teoria que eu construí, foi verificar que não tinha sentido o sistema explicativo da teoria da aculturação. Toda antropologia se alimentava dessas teorias. Segundo certa teoria norte-americana, os índios em contato com a civilização vão se interinfluenciando naturalmente. Traços de uma cultura vão passando à outra e eles vão ficando cada vez mais parecidos, com a eventualidade de se fundirem. Essa é a teoria geral aculturativa. Eu me lancei contra a teoria aculturativa mostrando que, primeiro, a relação não é igualitária, os brancos absorveram tudo que podiam absorver no primeiro século, e depois já não tinham nada que dar. Não tinha mais relação de troca. Depois, nunca houve possibilidade dos índios receberem alguma coisa em compensação. O que a sociedade oferecia a eles era um lugar subalterno. Era uma sociedade de classes que tinha classes inferiores, oprimidas, e o lugar do índio seria debaixo da classe mais oprimida. Então a oferta não era uma oferta aculturativa, nem de convivência igualitária.

Era lugar comum na cultura brasileira, como ainda hoje também, a idéia de que os índios eram evangelizáveis, de que uma boa missão converte. Eu fui vendo que nunca ninguém converteu ninguém, levantei, por exemplo, aqueles dados do Nóbrega, que quarenta anos depois de estar aqui diz: "Com um anzol os converto, com um anzol os desconverto.” E chega à convicção de que só Deus pode iluminar a fé no coração dos homens. O fato é que nunca ninguém converteu ninguém. Tem índios, como os Bororó, com cento e cinqüenta anos de contato, ou os do Rio Negro, e isso não levou a nenhuma conversão. E claro que os padres fazem coisas perversas quando pegam crianças de tribos diferentes e as colocam em internatos que, para se comunicarem entre si precisam falar o português. Assim, eles criam marginais. As meninas criadas no Rio Negro, nessa situação, serviam para ser putas em Manaus, porque não prestavam mais para ser índias, nem prestavam para ser nada. E a mesma coisa fizeram muitas outras missões, insistindo na idéia de que a tarefa de proteger o índio era do missionário e que o missionário, evangelizando, incorporava o índio à civilização. E a teoria geral da cultura brasileira é a teoria da evangelização, segundo a qual, o governo deve ficar dando dinheirinho às missões religiosas para irem lá converter os índios, ou seja, cristianizar. A tarefa das missões é estender a cristandade, estender a europeidade, é matar os povos, é a tarefa terrível de 
catar qualquer povo do mundo que tenha uma fé qualquer e quebrar a alma deles para convertê-los em cristãos, uma coisa que só se faz com muita violência. Com populações indígenas nunca se conseguiu conversão alguma.

Pois bem, com base na minha experiência, eu conhecia mais índios do que qualquer outro. Eu não era um etnólogo universitário, eu tinha passado anos no sul de Mato Grosso visitando as tribos de lá, eu passei meses no Xingu, passei muito tempo no Amazonas, passei muito tempo no Maranhão. Eu conhecia mais índio do que qualquer pessoa. Eu não só estava preparado para conhecer e observar, como tivera, na minha vida, uma oportunidade de observação mais ampla do que qualquer outro. Mas, não estava satisfeito com isso e para escrever meu trabalho para a Unesco, fui a São Paulo ver os Kaigang de Bauru e passei uma temporada lá, para ver índios que, em 1918 impediram que a estrada Noroeste do Brasil seguisse de Bauru para frente. Eu estive nas duas aldeias indígenas Kaigang e vi índios muito aculturados, no sentido que os costumes se pareciam com os do caboclo, o modo de se vestir também. Mas índios, sentindo-se índios e sabendo-se índios. Saí de lá e fui procurar o grupo mais interessante que encontrei: os Xokleng de Santa Catarina, grupo este que o Von Ihering queria que o governo mandasse matar porque estava em guerra contra os amiguinhos dele, os colonos alemães de Santa Catarina. Essa briga deu na criação do Serviço de Proteção aos Índios. Eu fui para lá e passei meses estudando o caso. Cheguei lá, vi os índios várias vezes, falei várias vezes com eles, fiz observação, mas o que fiz, sobretudo, foi ler o relato de Eduardo Hoerhan, que era o encarregado da pacificação e que passou mais de trinta anos com o grupo que ele tirou da mata: um grupo aguerrido, de um vigor formidável. Eduardo pacificou-os em 1918 e sofreu ao ver a transformação desse povo. É uma história dramática que reproduzo na minha revista Carta [n. 9, 1993], publicada pelo Senado. Nesse caso, também era evidente como os índios foram se aproximando da civilização sem deixar de serem índios.

A base de tudo isso é que escrevi vários artigos examinando fatores como convívio e contaminação, os efeitos das doenças, os efeitos da integração econômica. Escrevi vários trabalhos e o Wagley e o Harris publicaram um resumo disso tudo. Depois houve uma briga minha com o Metraux, porque eu mandei um texto provisório para ele, e ele contratou a Plom, e eu briguei com ele, escrevi para a Plom proibindo a publicação. Acontece que eu sou muito perfeccionista. A mesma coisa aconteceu comigo, agora: esse livro que acabo de publicar $O$ povo brasileiro. Fiquei 30 anos melhorando e estou sempre achando que posso fazer mais. Mas, como ia morrer, estava no hospital com 
câncer para morrer, fiquei com pressa e acabei o livro em quarenta dias. Levei trinta anos escrevendo, pensando, pensando. Esse livro é o mais pensado.

Da mesma forma, o livro da Unesco também, eu levei dez anos pensando e só larguei no exílio, com o título de Os índios e a civilização. Lá, eu faço uma reconstituição dos contatos dos índios com a civilização no século XX, quase que tribo por tribo. Depois, faço um balanço crítico da ação protecionista. Desenvolvo a teoria da transfiguração étnica, ou seja, há um processo natural, cultural, de transfiguração étnica através do qual um povo permanece ele mesmo à medida que muda e se adapta às condições de sobrevivência. Trata-se de um processo de autoconservação em que eles vão conservando o que é possível de sua cultura, mas não se fecham: quem se fecha, morre e desaparece. Então, o que ocorre é uma transfiguração étnica. Com esta concepção a gente entende os índios que estão no Brasil, os estados em que eles se encontram e os problemas que sofrem. Eu mostro que a transfiguração étnica passa por etapas que não são sucessivas, podem ser simultâneas, uma pode faltar, mas que são remarcadas. Há, primeiro, uma interação ao nível biótico: seres humanos se encontram como portadores de micróbios e enfermidades. Esse encontro ao nível biótico é o que mais matou. Chegou o europeu trazendo doenças tais que mataram um milhão de Tupinambá aqui na costa, como a varíola, no século XVI. Então essa interação biótica precisa ser levada em conta, porque ela é fundamental no processo de transfiguração. Depois há uma interação de ordem ecológica: quando entra alguém, derruba a mata, planta capim e põe gado, as condições ecológicas se transformam. Nas tribos do Nordeste sobre as quais se sabe tão pouco, a expansão do gado tirou o índio, em função de uma sucessão ecológica em que, uma nova população, com uma nova forma ecológica de adaptação se instalou; destruindo a interação biótica, a interação ecológica e econômica anteriores. Deste modo é que o índio é convertido em condição material de prosperidade do outro, não existe mais para si, existe para o outro. Sofre todo tipo de opressão econômica para intercambiar bens que se tornam indispensáveis para ele. Além disso, ao nível sócio-psicológico, há toda uma série de traumas, de problemas, de tensões que são o aspecto mais espiritual da transfiguração.

Meu livro sobre transfiguração é a tentativa mais copiosa e mais ambiciosa de uma interpretação do que se sucedeu com os índios. É claro que, depois, outros estudos foram sendo feitos, complementando o meu. Outra coisa que há no meu livro era uma relação de todos os grupos que existiam no Brasil, uma avaliação de quantos eram. Eram mais ou menos cem mil. Eu tinha todos os elementos, na época, para fazer este levantamento: o contato com 
os postos do SPI, o contato com o arquivo do SPI, o contato com missionários e, com base nisso, eu fiz a primeira lista circunstanciada de cada tribo e fiz uma classificação, que ainda hoje se usa. Classifico esses índios em isolados, sem contato direto com a civilização, em que há mais erro porque apareceram mais grupos depois da minha publicação; índios em contato intermitente, que têm um contato hoje, outro amanhã; índios em contato permanente e índios integrados. Esse "integrados" foi muito mal interpretado em decorrência de uma leitura ignorante, segundo a qual, integrado era integrado à sociedade nacional. O que eu digo é diferente, trata-se de uma integração no sistema de produção nacional: os índios chegam a um ponto em que não podem viver sem trabalhar para ter um salário, não podem viver sem produzir alguma mercadoria, sem se alugar como mão-de-obra. Essa integração não é nenhuma assimilação, toda minha teoria é de que não há assimilação, há uma compulsória integração. As fronteiras da civilização avançam, envolvem grupos indígenas e eles, inevitavelmente, integram-se ao sistema, estão ali, não podem se negar a isso, mas não estão integrados, toda questão é que não há assimilação.

E, como o livro foi feito por mim, depois de ter trabalhado no SPI, há também, alguns antropólogos bisonhos que têm o seguinte tipo de postura: o pensamento do Darcy está contaminado porque ele era funcionário e, como funcionário, tem um pensamento impuro. Esta é a mesma atitude "filha da puta" de um sociólogo que dizia que Mário de Andrade e Carlos Drummond de Andrade eram sem caráter porque trabalhavam para o Getúlio. Mas eles foram os quadros culturais que criaram o Ministério da Educação, que criaram a arte moderna no Brasil, que dizer, atacá-los como getulistas é de uma burrice cavalar. Estas pessoas não compreendem coisas fundamentais, que no meu livro ficam claras.

Outra incompreensão deste tipo refere-se à política implementada por Rondon. Foi um passo imenso, dado graças ao positivismo, que o Estado abrisse mão da ação missionária na condução da questão indígena para assumi-la como questão do Estado leigo. Uma primeira consequência disso é que a terra indígena, ao invés de ser reservada em nome da missão, passa a ser reservada em nome dos índios, e há mil consequências importantes que decorrem do fato da proteção estar nas mãos do Estado. Em segundo lugar, pela primeira vez no mundo se faz uma legislação, no Brasil, ao contrário da tradição liberal. A tradição liberal, em nome da liberdade, mandava que os índios fossem tratados como iguais, isso liquidou com os índios do Peru, do México, porque eles eram tão livres que a terra que tinham, podiam vender, e alguém comprá-la por uma garrafa de cachaça. Então aqui, a legislação 
é uma legislação totalmente nova, que dá ao índio uma igualdade relativa, assegurando-lhe todos os direitos que tem o cidadão comum, sem cobrar os deveres. Dá a ele um direito de cidadania, mas estabelece uma tutela que, aparentemente seria ofensiva, porque compara o índio com um menor de idade, mas isto não era feito para ofendê-lo, pelo contrário, era feito para que a terra dele não fosse roubada. Então, essa igualdade relativa é uma grande coisa em direito, tão grande coisa é, que isso foi feito pela primeira vez no mundo, na legislação brasileira, em 1910 e é ultima palavra nos Estados Unidos. Lá, o direito compensatório trata o negro como diferente, porque ele teve uma história diferente, dá direito especial à Universidade, ainda que não esteja tão bem preparado. Essa aceitação da realidade na lei, ao invés da brutalidade liberal do "morra quem morrer que no fim vai dar certo" é uma coisa muito importante que ocorreu então.

Há uma incompreensão quanto a isso e, às vezes, há pessoas que lêem os meus estudos sobre contato com a ingenuidade de querer interpretar a história, a partir de valores subalternos, sem uma capacidade de comparar com o que havia antes, e com o que havia como alternativa viável naquele momento.

E como o Sr. definiria seu novo livro $O$ povo brasileiro? Que tipo de recepção o Sr. acha que o livro terá? Ele seria uma continuidade deste conjunto?

Esse conjunto me levou mais de dez anos para ser escrito, hoje tem 170 edições nas principais línguas $\mathrm{E}$ o conjunto de uma obra teórica, de um brasileiro, latino-americano, mais traduzido e mais discutido, porque está quase todo ele em todas as línguas principais. Mas esse conjunto não me era ainda satisfatório. Depois do exílio, quando eu vim para cá, por volta de 1980, eu tornei a escrever uma terceira versão completa de um outro livro, mas não estava satisfeito. O tempo foi passando e eu acabei sendo hospitalizado, numa UTI. A UTI me horrorizava, a UTI é uma câmara da morte, eu passei 21 dias na UTI. E verdade que a UTI me salvou: eu estava com dor, pneumonia, liquidado em função de um tratamento de quimioterapia para o meu segundo câncer. Mas a minha angústia era enorme, parece até inverossímil, pois eu queria viver e eu sabia que se eu ficasse na UTI eu iria morrer. Eu queria viver e eu queria terminar esse livro. Você calcula, eu tinha 170 edições de 5 livros. Tinha que completar esse conjunto com mais um livro. Então, para mim, era de uma importância enorme. Eu fiz uma guerra tremenda e acabei obrigando a fazerem uma UTIzinha, num apartamento, porque eu não agüentava ver aquela gente morrendo ao lado. Mas eu queria fugir e eu ameaçava o médico 
de que se ele não me deixasse sair, eu ia suicidar-me. O médico ficava apavorado, ele tinha medo de mim. Eu ficava dopado, quando eu saía da dopagem eu xingava o médico, a mãe dele. Eu fazia o diabo porque eu estava loucão para sair daquela casa da morte. Um dia, eu estava ameaçando me suicidar se o médico não me deixasse passar o ano novo em casa, em Copacabana. Ele deixou e, quando eu me vi no carro, estava o meu sobrinho que é um homem sério, que garantiu ao médico, deu um recibo para ele, que ia me trazer no dia seguinte. Quando chegou na esquina, que o carro ia virar para Copacabana, eu disse: "Não vou para Copacabana, eu vou para Maricá.” Ai meu sobrinho disse não, e comecei a discutir com ele, coloquei-o para fora do carro e disse: "Vá para fora seu filho da puta." Aí chamei o Jairo, que é o marido da minha chefe de gabinete. Disse: "Senta aí Jairo e vamos para Maricá.”.E eles que estão acostumados a receber as minhas ordens, a trabalhar comigo, entraram no carro e tocaram para cá, para Maricá. Eu consegui fugir do hospital. Então vim aqui para Maricá e fiz uma completa loucura: no caminho, no último posto de gasolina, tem um lugar que vende caldo de cana e eu gostava de caldo de cana espremido com limão, que dá um tipo de bebida que eu gosto. Eu estava há 21 dias sem comer, vivendo de soro, e eu disse: "Traz um copaço de caldo de cana para mim.” E ele foi lá e trouxe. Eu bati aquele copaço, uma maravilha. A minha barriga que não via nada há dias reclamou. Quando eu cheguei aqui tive uma caganeira que foi um horror. Eu expelia bosta por tudo que era lado (risos). Mas eu creio que isto me curou. Aí mandei trazer para cá o computador e chamei outra secretária, a Gisele, que é a minha assessora principal, peguei as versões antigas do livro e fui ditando a versão final do O povo brasileiro. Eu o fiz aqui em um mês e tanto. E claro que o livro estava todo na minha cabeça, só que de uma forma insatisfatória e eu o refiz de uma forma que me deixou satisfeito. Ficou bom, ficou o que eu queria. E esse livro foi editado, em um mês saiu uma edição e oito reimpressões e em dois meses vendeu 80 mil exemplares: é o primeiro livro meu que tem um sucesso grande assim, mas o sucesso não é tanto pelo livro, é porque o cara para escrevê-lo, estava com câncer, câncer dá muito prestígio, fugiu do UTI... (risos).

Então tudo isto teve um efeito bom porque afinal eu consegui coroar a minha obra.

Desde 64 que eu estou trabalhando nisso e a essa série eu chamo "Estudos de Antropologia da Civilização”. Mas além disso há a minha obra de etnologia indígena, que é uma obra copiosa, há os livros que eu publiquei sobre religião, mitologia, arte indígena, e que constituem um capítulo que eu não posso jogar 
fora, não posso desprezar. Mas o importante mesmo quanto a índio é $O$ índio $e$ a civilização em que eu trato do destino dos índios, em que eu trato os índios como uma gente humana, como populações humanas que sofreram um terrível drama e em que analiso e teorizo.

Quanto ao Povo brasileiro, esse livro acabou por fazer parte dos meus estudos de antropologia da civilização. Para mim seria uma frustração tremenda se eu morresse sem escrevê-lo. Agora, até que eu estou livre para morrer.

Nem tanto: os jornais noticiam que o Sr. está escrevendo um novo livro!

É verdade. Enquanto isso não acontece, estou fazendo uma coisa que está me dando muito prazer. Eu fiz uma pesquisa de dois anos nos anos 50 entre os índios Urubu-Kaapor, que ficam no rio Gurupi, que é fronteira entre o Maranhão e o Pará. E a segunda tribo à qual me dediquei totalmente, porque eram os índios mais próximos dos Tupinambá que viviam na costa em 1500.

Mas, em 500 anos, a língua deles mudou, os hábitos deles mudaram e eles são outros, mas são outros muito próximos, os mais próximos. Então se pode estudar os Tupinambá, como o Florestan Fernandes estudou, por exemplo, com base na documentação dos cronistas, de 1500 a 1600, que descreveram os Tupinambá. Florestan fez uma obra extraordinária, seu livro, Organização social dos Tupinambá, foi feito como uma tese funcionalista com base na documentação dos cronistas.

Eu me treinei para outra coisa: para ir ler na realidade. Então fui procurar uma tribo, a mais próxima dos Tupinambá para estudar o que eram as populações indígenas brasileiras. Então fiz duas grandes expedições entre esses índios. E em todas as minhas expedições, eu fazia sempre diários. Tenho diários que estão em umas 800 páginas datilografadas que são os diários das duas grandes expedições que eu fiz em 49 e 50/51, entre os índios Urubu-Kaapor. Eu sempre pensei que ia ter tempo, em algum momento, de me dedicar intelectualmente a esse material, mas quando acabou isso começou a minha vida de ministro, de ser político, de fazer a revolução brasileira, de ir para o exílio, de fazer uma teoria do Brasil, uma teoria do mundo. Mas a minha idéia, até há algum tempo atrás era a de que eu ia subsumir daquelas 800 páginas de diário, a sua religião, a sua mitologia, a sua economia, a sua arte, para publicar mais uma monografia. Mas de repente, caí em mim, de que isso é uma loucura, uma bobagem, porque não é verdade, não há uma ideologia sem uma religião, sem uma economia, sem uma arte; está tudo misturado. Por isso tudo, é muito mais verdadeiro o meu diário, então eu tomei a decisão de refazer o diário, e estou terminando agora.

Esse diário é uma espécie de convite: venha leitor, venha andar comigo 
mil quilômetros, aldeia por aldeia, vamos visitar cem aldeias, conhecer as pessoas que estão lá, o que elas estão fazendo, se tem um batizado, como é que batizam, se tem um casamento, como é que casam. Venha comigo ver! Então na realidade, eu creio que vou dar um livro ao leitor, mais legível, porque é um livro em que, dia-a-dia, eu descrevo a minha vivência com os índios, tem coisa como essa, por exemplo, que causava muita impressão, entre os militares: quando eu estava preso, contar que havia realizado uma marcha de 700 quilômetros impressionava muito, porque para qualquer milico, andar cem quilômetros é muito, e eu tinha andado, com meus pés, 700 quilômetros, numa dessas expedições, à pé, na floresta. Isso era extraordinário.

O leitor tem a possibilidade de me acompanhar e de ter uma aventura espiritual. É claro que uma das coisas bonitas e estranhas é que a metodologia é toda contraditória, uma hora eles me contam uma coisa, outra vez me contam outra, e mais outra versão; e se eu fosse fazer um livro na forma de uma monografia, eu ia subsumir daquilo o que decidisse que era a verdade; e, para os índios nada daquilo é verdade, porque tudo é verdade. Então é muito mais verdadeira essa exposição larga, ampla, do que eu vi em cada aldeia. E é muito engraçado porque o negócio já está tendo êxito. Depois que o meu editor viu uma entrevista que dei num jornal, onde afirmei que ainda não tinha decidido quem vai editar, mas que há uma proposta francesa e há uma no Brasil, ele me telefonou e disse: “mas Darcy eu mandei para você o contrato, eu quero o livro”. Você vê, é raro você ter um livro que o editor já está brigando, antes dele ser feito. E eu estou dedicado a isso. E é muito bom, porque é tão bom como escrever um romance.

\section{O Sr não falou ainda de seus romances. Como é essa sua faceta de romancista?}

Romances. Não vou dar muitos detalhes sobre isso, mas digamos, quando eu estava escrevendo $O$ processo civilizatório, eu fiquei meio doido. Eu trabalhava tanto, dia e noite, que eu entrei em paranóia. Eu lia uma página três vezes, mas não entendia nada. Fui procurar um médico, porque eu achei que estava louco. O médico, um uruguaio paciente, me ouviu uma vez, me fez ir lá outra vez, e me disse: "Olha professor, o senhor tem que sair dessa, o senhor tem que descansar um pouco, tirar essa preocupação da cabeça..

E eu estava tão doido, que fui passar quinze dias fora para descansar, quinze ou vinte dias. Fui para um hotel de verão no inverno, então o hotel não tinha nenhum conforto, não tinha ninguém lá naquela época do ano. Havia uma senhora italiana que me alugou um quarto. Eu cheguei lá e ficava lendo o dia inteiro, lendo, lendo, lendo, e ela, no segundo dia me disse: “O senhor 
veio para descansar e fica só lendo aí. E olha, eu preparei para o senhor esse vinho.” Ela pegou um litro de vinho e colocou na lareira, o vinho estava quase fervendo, pôs na mesa do almoço e disse: "Olha, é para o senhor beber quando o senhor quiser, esse vinho é nosso, fazemos aqui mesmo, mas é bebível.” E eu bati aquele litro de vinho. No estado em que eu estava, tomar um litro de vinho, me deixou loucão. Mas aí eu percebi uma coisa: eu tinha uma espécie de polvo na minha cabeça e pensei que a única forma de me livrar desse polvo era pôr outro. Então eu disse: "Eu vou escrever um romance."

Passei a fazer um esforço enorme para escrever um romance e tive a idéia de Maíra. Era a idéia de um livro em que eu tomava uma história real, que é a história de Aipobureu, que é um índio Bororó que foi para Roma. O fruto, o produto nobre de dezenas de anos de trabalho dos salesianos, era aquele menino índio que eles estavam convertendo ao sacerdócio, e ele passou uns anos em Roma se preparando. Em Roma ele ficava duvidando se podia ser sacerdote ou não, e em sua volta vive o drama de, não conseguindo ser sacerdote, não consegue ser índio também. Então essa história, com muito mais coisa, é o que veio a ser Maíra. E eu fiquei quinze dias lá escrevendo, fiz todo esquema de Maíra, esquema que eu nem usei depois. Mas o que é incrível, é que quando acabei de fazer o esquema, eu estava curado. Voltei para casa, descansado, e três meses depois $O$ processo civilizatório estava pronto. Ou seja, não é fazendo nada que você descansa, mas fazendo outra coisa. E no trabalho intelectual, se você deixa um por outro, isso te descansa completamente, e eu não parei um dia de trabalhar com a cabeça.

Depois, quando eu voltei para o Brasil, fui preso por nove meses e passei uns dias preso num lugar horroroso. Primeiro me puseram preso, para me humilhar, numa prisão de soldados. Mas milico tem juízo, não persegue muito quem foi poderoso, porque pode voltar a ser. Então acabaram me tirando daquela prisão em que a privada era um nojo. E me levaram para um lugar melhorzinho que eles tinham, que era o Clube dos Cabos. Os cabos tinham uma área muito grande, com muita mesa de pingue-pongue, que era para eles se divertirem, e tinha um quartinho fechado e bem ventilado, onde me puseram, na véspera do Natal. E eu passei risco de vida ali, porque a porta ficava fechada, mas tinha só meia parede, então de vez em quando voava garrafa de coca-cola que os soldados jogavam para mim, e eu vivia com medo, pedaços de bolo que vinham da mesa de Natal.

Naquele lugar, eu pedi papel e escrevi um outro esquema de Maíra. Depois escrevi mais outro, até que cheguei à versão final do livro que eu escrevi no exílio do Peru onde eu já disse que, enquanto escrevia o livro, estava 
vivendo com os índios. Fui compondo o livro até ter a forma que tem.

O livro me surpreendeu, primeiro, porque eu não tinha nenhuma intenção de fazer isso, mas um tema profundo do livro é a morte de deus, o deus dos índios vai morrer, está morrendo, porque o mundo não tem remédio; aquele mundo deles, o que era original, está morrendo. Há um capítulo em que o próprio deus diz: "Que deus sou eu, o que está acontecendo, se o meu povo desapareceu, quem é que vai me adorar?” Então, o tema profundo é esse sentimento que me afeta, do mundo indígena estar se descaracterizando. Eles vão continuar existindo, existe mais índio hoje do que ontem, vai haver mais índio amanhã do que hoje, mas eles serão outros, serão índios, mas mudam como tudo muda. Outra descoberta que eu fiz, é que, sem querer o livro tinha a estrutura da missa católica, que é a morte de deus também. Então, quando eu descobri que ele tinha a estrutura da missa eu o dividi em capítulos como os capítulos da missa católica. E o livro se escreveu a si mesmo.

E tem um livro que para mim foi uma aventura de aprender o caminho da literatura. A primeira coisa que eu fiz na minha vida foi, aos vinte anos, escrever um romance. Eu era estudante de medicina, e tomava bomba todo ano, era reprovado todo ano e pensava seriamente em me suicidar. Agora, eu estudava medicina, não ia à faculdade, e escrevi um livro de trezentas páginas. Nenhum estudante de medicina escreve um livro de trezentas páginas. Se escreve, tem que tomar bomba. Então, a primeira coisa que eu fiz na vida foi esse romance, que eu ainda tenho uma cópia dele, felizmente não foi publicado. Mas eu tinha um grande interesse nisso, depois fui estudar antropologia, depois fui estudar os índios. Havia tanta seiva na vida indígena, os índios me refizeram, e me transformaram em um intelectual atípico.

Eu retomei o interesse por literatura, no exílio, primeiro, para descansar, e depois, no Peru. No Peru eu estive um período muito grande. A minha ida para o Peru foi, ao mesmo tempo, um equívoco e um acerto. Eu era assessor do Salvador Allende, não via nenhuma possibilidade do Brasil chegar ao socialismo, ou fazer uma reforma eleitoralmente. Um erro, você vê agora, nas duas últimas eleições, a votação principal foi para a esquerda, e se o PDT e o PT estivessem unidos, com um projeto próprio, poderiam ter ganho. Quer dizer, há essa possibilidade no Brasil, mas eu não via. Quando eu fui convidado pelo Carlos Delgado, um intelectual peruano, para ir para o Peru, eu conversei com o presidente. Ele me disse que eu vinha para ajudar a pensar a revolução peruana, e eles estavam fazendo uma profunda reforma agrária, a mais profunda que houve na América Latina, tentando mudar as coisas, mudar a imprensa, mudar tudo. E eu me interessei 
muito por aquilo. Mas eu fui vendo, custei a compreender, que havia um trauma dos militares contra os intelectuais como Carlos, como Pancho, e como outros que estavam entregando os dados a um brasileiro, para ele estudar a revolução. Isso era uma coisa humilhante para eles. E alguns milicos não aceitavam isso.

Mas eu estava interessado nisso e preparei todo um sistema para colocar o Peru no que eu chamava de "socialismo cibernético" que era o seguinte: eu preparei tudo para que, se os peruanos me dessem os dados que tinham sobre o Peru, eu colocaria no computador um Peru artificial, um Peru computacional, com o número de mulheres que tinha, o número de crianças, velhos, escolas, todo Peru lá dentro, de forma que eu pudesse mover esse Peru para a frente, para ver vegetativamente o que aconteceria com ele dentro de dez, vinte anos.

Mas se sabe que qualquer previsão vegetativa não dá certo, nunca deu certo. O que nós queríamos fazer era uma coisa sacana: era saber o que o Peru precisava para se tornar, dentro de vinte anos, o que a Argentina era em 1950. Nós decidimos acoplar os dados da Argentina aos dados peruanos e descobrir que etapas seriam necessárias para que o povo peruano chegasse às mesmas condições da Argentina. Era isso que eu queria fazer e a idéia básica disso tudo era o seguinte: um socialismo não é só uma teoria filosófica, é uma possibilidade de reordenar a vida para que a vida seja mais confortável para mais gente, e o computador permitia fazer isso. Mas os putos dos peruanos nunca me deram os dados, ficaram me enrolando. Como tenho uma capacidade de trabalho intelectual muito grande, eu preparei tudo durante uns meses, estava animado e com uma equipe muito boa. Mas na hora de entregarem os dados, me enrolavam e não me deram nada.

Mesmo assim, o Peru foi bom porque eu tive bastante tempo lá para usar a cabeça no que eu queria. Tive tempo para escrever Maíra, horas e horas, porque toda minha potencialidade intelectual estava desocupada. Então eu escrevi um romance longo. Depois, como eu gostei dessa experiência, ainda no Peru, eu escrevi praticamente todo um outro livro que é $O$ mulo, ali eu conto as minhas memórias de até os 17 anos com a minha família. E eu estou impregnado de memórias da minha gente. É uma gente bruta, e o livro é uma espécie de romance social ao contrário. Em lugar de fazer como Jorge Amado, mostrar que o povo é bonito, e que o povo vai fazer a revolução, eu entro na cabeça de um senhor da classe dominante, que descreve o povo com todo aquele preconceito, que era a minha gente. O livro é uma maravilha. Publicaram páginas inteiras no Globo contra mim, dizendo que tudo que estava escrito era o que o Darcy pensa (risos).

Outro livro meu é Migo. Eu passei seis meses em Minas por alguma razão 
específica. Tive folga lá e decidi escrever um livro engraçado. A primeira parte do livro é minha história infantil. Mas depois é o seguinte, eu imagino como seria se eu tivesse ficado na província, em Minas, e fosse um intelectual mineiro, um intelectual provinciano, mineiro, com muita inveja dos que estão no Rio de Janeiro, de um Darcy Ribeiro, por exemplo. É um livro que tem como um de seus temas, a palavra, o poder da palavra, o poder incrível que a palavra dá ao homem. E o livro é uma brincadeira com isso, porque o personagem principal, de vez em quando ele diz, isso é conversa do Darcy, besteira, nunca se passou isso comigo, e o Darcy fala mal dele também. E eu inventei um personagem que é o diabo. É uma maravilha o tal do diabo, porque ele lê a história de cada personagem que está no romance, e ele vê a verdade do personagem. Esse livro, eu pensei que ia ter um grande êxito em Minas, que todo mundo ia adorar o livro, porque é um livro do meu furor patriótico mineiro. Mas o êxito foi pequeno.

Outro romance é Utopia selvagem, um livro pequenininho, que é muito engraçado, porque o livro é sobre um negro que cai numa tribo de amazonas. Todo dia ele come uma e depois morre de medo porque ele pensa: "Qualquer dia chegam os homens dessas donas, e eles vão acabar comigo.” Mas depois ele descobre que não tem homem nenhum, porque elas comem os seus homens, quando já não querem mais, e que ele vai ser comido. Então o negro que está lá fica apavorado. Esse livro é uma sátira da América Latina, e o fato é que no Brasil tem várias edições, todo mundo riu muito, gostou do livro. Inclusive os alemães pegaram e fizeram 160 notas de pé de página, para mostrar que o livro é eruditíssimo, porque cada frase é de um autor tal. Deram cursos na Alemanha e também no México sobre este livro.

Há, ainda, um outro livro: é Uirá, que conta uma história verdadeira, e foi feito um filme sobre esse livro. É um texto de umas quarenta páginas com a reconstituição da vida de um índio que sai à procura de deus. Pronto, aí vocês têm o Darcy completo.

Quando eu escrevi o meu romance Maíra, naquelas mil horas, ou naqueles mil dias em que eu estive escrevendo Maíra, eu não estava exilado, porque Maíra me devolvia a minha vida entre os índios. E agora muito mais com esse diário eu me recupero. Tem aqueles retratos todos, daquela época. São cem fotografias selecionadas que eu fico olhando para elas, de duas mil, que eu tenho. Então, eu me vejo com trinta anos, cheio de calor humano, convivendo com aquela gente. E me dá um sentimento de estar revivendo aqueles dias. Nunca escrevi uma coisa tão gratificante como esses diários. Eu vou chamar o livro provavelmente de Diários índios. E isso é o que eu estou fazendo agora. 